Série des Documents de Travail

\author{
$n^{\circ}$ 2011-34 \\ Migrant Networks as a Basis \\ for Social Control : \\ Remittance Incentive among \\ Senegalese in France and Italy \\ I. CHORT $^{1}$ - F. GUBERT ${ }^{2}$ \\ J.-N. SENNÉ ${ }^{3}$
}

Les documents de travail ne reflètent pas la position du CREST et n'engagent que leurs auteurs.

Working papers do not reflect the position of CREST but only the views of the authors.

\footnotetext{
1 Paris School of Economics (PSE).

2 IRD - UMR 225 DIAL - Paris School of Economics (PSE).

3 CREST (ENSAE) - Paris School of Economics (PSE) - UMR 225 DIAL.
} 


\title{
Migrant Networks as a Basis for Social Control: Remittance Incentives among Senegalese in France and Italy*
}

\author{
Isabelle ChorT ${ }^{\dagger} \quad$ Flore GuberT ${ }^{\ddagger} \quad$ Jean-Noel SennE ${ }^{\S}$
}

\begin{abstract}
The economic literature provides much evidence of the positive impact of social capital on migrants' economic outcomes, in particular through assistance upon arrival and insurance in times of hardship. Yet, although much less documented, migrant networks may well have a great influence on remittances to their home country and particularly to their origin households. Given all the services provided by the network, the fear of being ostracized by network members and being left with no support could provide incentives for migrants to commit to prevailing redistribution norms. In this perspective, remittances may be a fee that migrants pay to get access to network services. In this paper, we thus analyze to what extent migrant networks in the destination country influence the degree to which migrants meet the claims of those left behind. We first review existing models of remitting behavior and investigate how way the potential role of networks could affect their main predictions. We then provide a simple illustrative theoretical framework to account for the double impact networks may have on remitting behavior, through the provision of services to migrants and the spread of information flows between home and host countries. We finally use an original dataset of 602 Senegalese migrants residing in France and Italy to explore the main predictions of our model.
\end{abstract}

Keywords: Remittances, migrant networks, asymmetric information

JEL codes: F24, F22, D82

${ }^{*}$ This research is part of a three-year project entitled "Migration and development in Senegal: an empirical analysis using matched data on Senegalese migrants and their origin households (MIDDAS)" funded by the French Agence Nationale de la Recherche and the Agence FranÃßaise de DÃ@Cveloppement. Fieldwork in Italy was conducted by Forum Internazionale ed Europeo di Ricerche sull' Imigrazione (FIERI), whose dedicated involvement in the MIDDAS project is gratefully acknowledged. We are also grateful for the excellent comments we received from participants to the CSAE 2011 conference, the third Migration and Development conference, the 10th EUDN PhD Seminar, and the first tempo conference on International Migration.

${ }^{\dagger}$ Paris School of Economics (PSE)

${ }^{\ddagger}$ IRD - UMR 225 DIAL - Paris School of Economics(PSE)

${ }^{\S}$ CREST(ENSAE) - Paris School of Economics (PSE) - UMR 225 DIAL 


\section{Introduction}

The economic literature provides much evidence of a positive impact of social capital and networks on economic outcomes through a reduction of transaction costs, access to and exchange of information. In particular, social capital has been found to facilitate access to the labor market and to improve wages and/or occupational status (see, e.g., Montgomery, 1991; Granovetter, 1995). This role is all the more essential for immigrants. Migrant networks, indeed, foster economic and social integration of immigrants in destination countries and, for example in the presence of discrimination in the labor market, may allow them to get access to a larger set of job opportunities (Lin, 1999; Bertrand, Luttmer, and Mullainathan, 2000; Topa, 2001; Edin, Fredriksson, and Åslund, 2003; Mouw , 2002; Munshi, 2003; Aguilera,2002; Aguilera, 2005; Patel and Vella, 2007; Drever and Hoffmeister, 2008). Networks have also been found to provide freshly arrived migrants with shelter and assistance, and, in the course of their stay, to offer them material support in times of hardship (Menjívar, 2002; Mazzucato, 2009). By providing information and assistance, migrant networks contribute to lower the costs of migrating and may play a role in shaping migration patterns as recently shown by McKenzie and Rapoport (2010). As for Senegalese migrants in France and Italy, the recent data that we collected in 2009 within the framework of the MIDDAS project (described in section 4) support the evidence that migrant networks play a key part along those two dimensions. On the one hand, we find that upon arrival, respectively $70 \%$ and $43 \%$ migrants found a place to live and a job thanks to kinship members or Senegalese non-relatives. On the other hand, most of them got support from their kinship or Senegalese network during unemployment periods. Data also suggest that those who found their first job by themselves stayed unemployed for a longer period.

Yet, another important feature of migrant networks is that they are means of communication between migrants and their relatives in their origin country. Networks convey information but may also vehicle social norms, and as such, may exert a control on individual behaviors in order to guarantee the cohesion of the migrant community and preserve the link to the origin country. This may be particularly the case in the Senegalese community which seems to be structured by demonstrated solidarity values. In this perspective, continuing interpersonal relationships established with kinship members or other co-ethnics may act as a constant reminder to the migrants of their commitment to their family and relatives back home. One specific consequence 
is that migrants are expected to remain closely connected with their origin country, thus inducing for migrants the obligation to send monetary transfers to those left behind, for fear of being condemned. And given the large amount of services networks can provide to them, ostracism and the fear of being left with no support can be an effective threat for migrants to prevent them from reneging on their remittance obligations.

Nevertheless, despite a pervasive and growing literature on remittance motives, very few papers investigate the specific impact of migrant networks on migrants' transfer behavior. Only a few empirical works (Sana, 2005; Roberts and Morris, 2003) follow after the anthropological material published by Philpott (1968) who argues that social control with regards to remittance obligations is largely rooted in migrant networks in the case of Montserratian migrants in Britain. In this paper, we try to fill this gap in the economic literature and investigate to what extent migrant networks, made up of family members, kin, fellow villagers or friends, may be related to their remittance behavior. To that end, we explore the double dimension of networks as services suppliers and communication device. We present here the idea that origin households may control migrants' access to network resources by manipulating reputations and spreading rumors through the very network.

Therefore, we first discuss the role migrant networks could play in existing models for remittance motives and present a basic theoretical framework that is general enough to encompass any other remittance motives, to illustrate their double function and give intuitions of their expected impact on migrants' remitting behavior. We then use original data on a sample of 602 Senegalese migrants residing in France and Italy to test the main predictions of our model.

The remainder of this paper is organized as follows. Section 2 draws on the existing anthropological literature to get some key insights on the main features of Senegalese migrant networks. In section 3, we synthesize the main results of the economic literature on remittance motives, discuss the introduction of networks in existing models, and develop a basic model allowing for network effects. Section 4 presents the survey data collected among Senegalese migrants in France and Italy and provides some descriptive statistics. Section 5 tests the main predictions of our model, performs robustness checks and addresses alternative interpretations of our results. Section 6 concludes. 


\section{Senegalese Migrant Networks: a Review of Ethnographic Ev- idence}

Due to strong data limitations, the economic literature exploring the role of migrant networks in the African context is rather poor. Existing studies mainly analyze the role of migrant networks on the migration decision. In the case of Senegal, a recent paper based on data from a nationally representative household survey suggests that migrant networks play a powerful role in shaping patterns of international migration from this country (Chort, 2011). Most of this influence may be attributed to the assistance and resources offered by the networks to migrant candidates in the origin country and to newly arrived migrants in destination countries.

Additional insights into the complex relationship between Senegalese migrants, their origin households and the Senegalese diaspora may however be found in the socio-anthropological literature. Regarding the matter in question, the recent papers by Mboup (2001), Elia (2006), and Dia $(2007,2009)$ are particularly instructive. Through in-depth interviews conducted among Senegalese migrants in France and Italy, they first provide strong evidence of network-based assistance and insurance mechanisms among Senegalese migrants.

According to Mboup who conducted a survey among Senegalese street sellers in Italy, newcomers arriving from Senegal are hosted by their fellow countrymen, offered free accommodation and credit to start their own business. In addition, Elia who studied this very circle of Senegalese street sellers in Italy documents the existence of mutual aid funds raised through a weekly tax among settled members of the group of migrants, that are granted to unlucky newcomers whose goods have been seized.

The above mentioned papers also provide evidence that networks convey forms of social control that reward conform behaviors in keeping with solidarity norms or, a contrario, condemn deviant ones. Information spread through the network may work as a mechanism of social control. Indeed, as information flows easily through migrant networks, the news (or rumor) of any misbehavior may be quickly communicated not only among migrants but also back to the home country. As suggested by Dia (2007), the new information and communication technologies, and in particular cellular phones, that are now widespread in Senegal have contributed to accelerate the diffusion of rumors. Information on misbehavior may also flow from origin households to network members in the destination country. In this perspective, the concept 
of "multi-located village" coined by Dia (2009) well accounts for the network structure of the Senegalese diaspora, as well as for the circulation of information between its members and the origin country. According to Dia, the overall control through reputation, by the use of rumor, plays as a permanent adjusting or re-adjusting mechanism for individual behaviors within the group. Remitting funds to those left behind (be they members of the origin household, the extended family or the community) is one of the behavioral standards Senegalese migrants are expected to conform to. Satisfying the financial requests emanating from the community of origin is thus socially rewarded.

By contrast, migrants not fulfilling their obligations expose themselves to the disapproval of their peers. Very interestingly, Elia (2006) mentions the translation of implicit control of peer migrants into clear warnings when individuals are considered to weaken the link with either the origin or the migrant community. This is especially so when they are reluctant to work or send remittances.

Pushing further their analyses, the authors provide several pieces of evidence showing that rumor spreading can constitute an effective means of controlling and influencing migrants' behavior. Indeed, as declared by one migrant interviewed by Elia (2006), deviating from the norm may be expected to result in ostracism and the concomitant loss of access to some network services or resources. Elia (2006) emphasizes that the social cost of isolation is very high because it means no more reciprocity links in the destination country as well as in the origin country.

Of course, one may wonder whether the control exerted by the network is a necessary condition for the migrants to commit themselves to send money to their relatives in their home country. It could indeed be argued that solidarity norms are strongly internalized by Senegalese migrants, especially as the great majority of them belong to the Islamic religion which considers alms-giving as an act of religious virtue. It could also be argued that migrants have altruistic feelings for those left behind, which ensures that they fulfill their remittance obligations. While it is true that altruism may enhance within-group cooperation, what the above quoted elements actually suggest is that migrant networks act as an enforcement device that helps cement such cooperative behavior. Thus emphasizing the role played by migrant networks does not mean that altruism is discarded. This issue will be further discussed in the empirical part of the paper. 


\title{
3 Network Effects on Remittances : A Theoretical Perspective
}

The literature on the theoretical and empirical determinants of remittances is quite broad. Rapoport and Docquier (2006) provide a comprehensive summary of the economic analysis of remittances, and in particular expose separately individual and household models, referred to as family arrangements. However, very few papers investigate the specific impact of migrant networks on remittances. Exceptions that include (Sana, 2005; Roberts and Morris, $2003 ;$ Kankonde, 2010) are all found in the anthropological literature. While those papers convincingly put forward the argument that networks deserve consideration, they do not provide any analysis of the economic rationale of network intermediation.

Our aim in this section is thus twofold: first, drawing upon the review provided by Rapoport and Docquier (2006), we recall the predictions of existing models in the literature and discuss the inclusion of migrant networks in these models, as well as ensuing results. Second, we present a very simple theoretical framework that highlights the double function of networks and the role it plays in migrants' remitting behavior. We keep it general enough so that it could be either included in or adapted to one of the existing models.

\subsection{Networks and Motives for Remittances}

Although many motives for remittances are theorized about in the economic literature, including for example altruism, intention to return, loan repayment, investment, or inheritance, they can be summarized more clearly by pointing out that they basically come down to two kinds of models: altruistic (individual) and exchange (household) models.

\begin{abstract}
Altruism
As emphasized by Rapoport and Docquier (2006), altruism has long been an assumption rather than a debated theory in the literature on remittance motives. Altruism has also been categorized among individual motives since it implies that migrants decide on their own initiative to transfer part of their income to their relatives left behind. However, since altruism technically refers to very particular utility functions where the satisfaction of others (household members in the home country) enters the utility function of migrants, the more general term of loyalty will be preferred. The main testable implication of the altruistic model is that transfers should
\end{abstract}


decrease with the recipient's income.

How do networks matter if migrants' remitting behavior is assumed to be driven by loyalty to those left behind? Under the assumption of pure altruism, networks are actually not expected to have any impact on remittances per se, once their potential positive effect on migrants' income is controlled for. Nonetheless, even though networks may have no direct causal impact on remittances in this framework, loyalty may conversely well drive both migrants' remitting behavior and socialization: migrants who prove more loyal to their home country are expected to be more inserted in migrant networks and be more likely to remit (and remit more). In that case, networks, rather than explaining remitting behavior, would be endogenously determined by the migrant's degree of loyalty. In the empirical part of the paper, we will thus put great care in testing whether our results are driven by altruism alone, or whether networks can be thought of as playing a role even when altruism is properly accounted for.

\section{Exchange}

All motives relying on household models can be considered as mere variants of a single exchange model: indeed, in this broad category of motives, remittances are assumed to buy goods or services offered by the recipient household. All motives for remittances but altruism can thus be derived from an identical theoretical framework. Indeed, while the nature of services provided by the household can range from taking care of the migrant's business, assets or relatives when he is abroad to providing insurance or credit services to him, mechanisms at stake are identical.

First, all these motives imply a contract between the migrant and his origin household, be it explicit or not. The temporal structure of the interaction between the two parties then depends on the type of services supplied by the household. Remittances and services may occur simultaneously when remittances buy services such as taking care of the migrant's relatives at home for e.g.; but they may occur at different periods of time if remittances are a repayment of loans which were used to finance the migrant's investment in education or his migration costs, or if remittances are part of a mutual insurance arrangement between the migrant and his family.

A second common feature of all household models is the existence of information asymmetries. The migrant and his origin household are by definition separated by geographical distance. Each agent's effort in complying with the agreed terms of the contract is thus at least partly 
unobservable to the other party, which raises monitoring issues. Except under the very strong assumption of perfect mutual altruism which would ensure that the contract is self-enforced, an enforcement device is thus required.

Network can easily enter into this setting as far as their double function of service providers and enforcement device is acknowledged. First, network resources can be seen as one of the goods or services to be exchanged. Indeed, what the above mentioned socio-anthropological literature suggests is that access to network resources is one of the services bought by remittances to the origin household. In this perspective, both the probability to remit and remitted amounts should increase with measures of past or present access to network services and use of network resources.

Second, networks may be used to balance information asymmetries between the migrant and those left behind. In particular, networks can vehicle information and rumors that may be useful to the origin household to monitor the migrant's behavior. Such a monitoring mechanism can prove an effective incentive not to deviate for the migrant if she expects to be punished, i.e. to be deprived of network resources once detected. If we further assume that the household can use the network to punish the migrant, then the network can be considered a strong enforcement device.

Of course, such an assumption may be debated: migrant networks could instead choose to conceal information to origin households and be reluctant to punish deviant behaviors. In that extreme case, networks would not affect remittances at all. However, anecdotal evidence and ethnographic surveys among Senegalese migrants suggest that networks do use various punishment schemes if necessary (and in particular ostracism) to get migrants to comply with their apparently unquestioned obligation to remit. Different elements can be put forward to explain such a mechanism. First, the network may shoulder a collective responsibility when one of its members fails to comply with prevailing norms of redistribution. The network may thus be careful to punish free-riders' behaviors that would deteriorate the relations of all migrants with the origin country. Second, the network, as a collective agent, is in between the origin and destination countries, and its strength relies on the link it establishes between both. If this link were to be cut, the network would lose part of its role and importance. Third, the network's composition is constantly changing, with new arrivals, deaths and migrants returning, which 
may block any attempt by the migrants to collude against those left behind. Fourth, due to the high degree of endogamy in origin communities, unmet remittance obligations are likely to either affect negatively the well-being of other network members' relatives or result in an increase in the remittance burden borne by those very network members. All those elements contribute to explain why migrant networks should punish any deviant behavior of their own members. Such enforcement mechanism is similar in this respect to that observed in the agency relation between Maghribi merchants and their agents overseas as described by Greif (1989).

We thus expect both the probability to remit and remitted amounts to increase with the size of the network, the frequency of contacts between the migrant and members of his network, the strength of the links between network members, etc. In the empirical section that follows, we will also differentiate networks depending on their type (formal Senegalese migrant associations vs. more informal groups of friends or relatives for e.g.), their homogeneity (relative to social status, geographical origin or age), or their composition (by members' date of arrival, nationality, etc.).

Beforehand, we present a very simple theoretical framework that aims at translating the mechanisms that have been presented so far into a more formal language.

\subsection{An Illustrative Model}

The model sketched in this section aims at representing in a very simple way the expected impact of migrant networks on remittances. As mentioned above, we expect networks to influence migrants' remitting behavior both through the provision of a large range of services and an information effect. We intend to conceptualize the idea that being granted an access to network resources might provide an incentive for migrants to commit to their remittance obligations. Since ostracism seems to be a credible threat and has a high social cost, we argue that remittances can be seen as stemming from a contractual agreement between the migrant and his origin household over network services that is enforced through the mediation of the very network. However, we do not exclude the possibility that other motives play a role, and provide a theoretical framework that is general enough to encompass them as well.

We consider the interaction between two agents, one migrant and his origin household, and specifically focus on one side of the agency relation. In order to emphasize the different roles played by networks in the presence of information asymmetries, we consider that the migrant 
chooses one contractual agreement among those proposed by his origin household, but has the possibility to cheat over the agreed contract terms.

Migrants are assumed to differ in their valuation of network services. The heterogeneity in migrants' types is represented by a $\theta$ parameter distributed in $[0,1]$. This assumption allows for altruistic motives for remittances: indeed, we expect migrants' valuation of network resources to be positively correlated with their loyalty to their origin household or country. This parameter is further assumed to be driven by variables capturing the migrants' reliance on network resources, such as their situation on the labor market in the country of destination, their intention to return in the home country or their insertion in other networks.

The household designs a menu of contracts that associate a given amount of network services to a corresponding level of remittances and network control: for more convenience, we assume that the household offers two different contracts, $(0,0,0)$ and $(b, t, \alpha)$, with $b>0$ the amount of network services, $0<t<1$ a "remittance rate", similar to a tax on the migrant's income, and $\alpha$ the characteristics of the network that are likely to affect the control it exerts on the migrant. The $b$ parameter captures various types of network services provided by family or fellow-countrymen to migrants in host countries (assistance to newly arrived migrants, insurance, etc.). The formulation is however kept general enough to encompass other exchange motives: indeed, $b$ may include a broad range of household services (education, insurance, loans, child caring) either network-mediated or not, in addition to network services, although we explicitly focus on the latter.

Once the contract is concluded, the migrant who self-selected into the non-zero contract remits to her household. Under the very plausible assumption that some of her actions are not perfectly observed by origin households, the migrant may exploit this feature to cheat over the agreed contract terms. This potential opportunistic behavior (moral hazard) is illustrated here by the fact that the actual amount of remittances is based on the migrant's declared income, denoted $\tilde{Y}$. The migrant may therefore choose to understate her income in order to remit less while benefiting from network resources.

This is the point where the network plays the role of enforcement device. Indeed, if we assume that the household has at least a partial control over the network, it may use network characteristics to monitor the migrant's behavior. The network is in position to collect infor- 
mation about the migrant since the latter is in contact with network members to benefit from network resources, and is thus likely to detect lying migrants. On the other hand, the network conveys information through the circulation of its members, meetings or merely frequent phone contacts between home and destination countries, and may thus be able to report migrants' misbehaviors to origin households. Note that, as emphasized above, we consider that it is in the network's interest to detect, denounce and punish deviant migrants. The possibility for network members to collude will be further discussed in the empirical section.

We thus assume that if the migrant lies about his income, he has a positive probability $q$ to be caught and punished. We consider that this probability increases with the difference between the migrant's declared and true incomes, and the $\alpha$ parameter $(0 \leq \alpha \leq 1)$ meant to represent the ability of the network to punish a deviant migrant, or its efficiency in collecting and conveying information. Consider in particular the case where the probability to be caught when cheating writes $q=\alpha f(Y-\tilde{Y})$, where $Y$ denotes the migrant's true income in the destination country, $\tilde{Y}$, the migrant's declared income $(\tilde{Y}<Y)$, and $f($.$) is convex \left(f^{\prime}>0, f^{\prime \prime}>0\right)$. Using a quadratic form for $f\left(\right.$.) which satisfies all these conditions, $q$ writes $\alpha\left(\frac{Y-\tilde{Y}}{Y}\right)^{2}$. We verify that $f(Y-\tilde{Y})=f(0)=0$ if $\tilde{Y}=Y$ (the probability to be punished is equal to zero when the migrant does not lie), and $f(Y-\tilde{Y})=f(1)=1$ if $\tilde{Y}=0$ (the probability to be caught and punished - is maximal and equal to $\alpha$, if the migrant declares a zero income). In order to keep the presentation simple, we further assume that if the migrant is caught, he has no longer access to network services. Under all the above assumptions, if migrant $i$ chooses the contract implying a strictly positive level of remittances, his utility writes:

$$
U_{i}=Y_{i}-t \tilde{Y}_{i}+\left(1-\alpha_{i}\left(\frac{Y_{i}-\tilde{Y}_{i}}{Y_{i}}\right)^{2} \theta_{i} b_{i}\right.
$$

else,

$$
U_{i}=Y_{i}
$$

The participation constraint for the migrant thus writes: $Y_{i}-t \tilde{Y}_{i}+\left(1-\alpha_{i}\left(\frac{Y_{i}-\tilde{Y}_{i}}{Y_{i}}\right)^{2} \theta_{i} b_{i}>Y_{i}\right.$. This inequality proves true for any $\theta_{i}$ positive, which means that if the possibility to cheat once abroad is internalized at the time when the contract is chosen, all migrants whatever their type 
choose the non-zero contract. Second,as regards remitted amounts, the migrant maximizes her utility (equation 3.1) with respect to her declared income $\tilde{Y}_{i}$ (which is her remittance base). If $Y_{i}<\frac{2 \alpha_{i} \theta_{i} b_{i}}{t}$, there is an interior solution characterized by:

$$
\tilde{Y}_{i}^{*}=Y_{i}-\left(1-\left(\frac{t Y_{i}}{2 \alpha_{i} \theta_{i} b_{i}}\right)\right)
$$

On the other hand, if $Y_{i}>\frac{2 \alpha_{i} \theta_{i} b_{i}}{t}$, we have a corner solution with $\tilde{Y}_{i}=0$. The intuition of this result is straightforward: if the tax rate is too high compared to the benefit the migrant can get through the network (as denoted by $\theta_{i} b_{i}$ ), then the migrant's optimal strategy is to choose not to remit. ${ }^{1}$

When there is an interior solution, the remittance base, $\tilde{Y}_{i}$, is found to be a quadratic function of the migrant's income $Y_{i}$. It is also found to increase with the network's efficiency or ability to collect information and punish the migrant $\left(\alpha_{i}\right)$; with the parameter representing the migrant's loyalty and needs of network services $\left(\theta_{i}\right)$; and with the quantity of services bought by remittances $\left(b_{i}\right)$. The above formulation also illustrates the intuition that interactions between all three parameters, $\alpha_{i}, \theta_{i}$ and $b_{i}$, may matter. Great attention will be put in investigating this particular point in the empirical analysis that follows.

\section{Data and Summary Statistics}

We focus our analysis on Senegalese migrants that have been surveyed in France and Italy through the MIDDAS project. Carried by a team made of French, Italian and Senegalese researchers, this project aimed at collecting matched data on Senegalese migrants and their origin households to investigate issues such as the role of origin households and communities in migrants' transnational practices; the impact of remittances on origin households; informational asymmetries between the migrants in destination countries and their households in Senegal; etc. ${ }^{2}$

300 Senegalese migrants in France and 302 Senegalese migrants in Italy were interviewed over

\footnotetext{
${ }^{1}$ While the migrant and his origin household may be expected to interact over several periods of time, dynamic aspects are not taken into consideration here. Contrary to Gagnepain, Ivaldi, and Martimort (2009), we do not investigate reputation issues and their consequences on contract renegotiation. In our model, the time dimension is thus limited to repeated interactions without learning. One alternative would be to consider that origin households definitively stop contracting with dishonest migrants once they are caught. However, such an assumption would not significantly change the predictions of the model.

${ }^{2}$ For further details on the MIDDAS project, see http://www.dial.prd.fr/dial_enquetes/dial_enquetes_ middas.htm
} 
the year 2009 using common sampling methodology and questionnaire. Detailed information on migrants' personal networks in France and Italy has been recorded together with data on remittances sent to the origin household and home community, savings, investment projects and migrants' individual characteristics.

\subsection{Sampling Method}

Any attempt to carry out a survey focused on migrants faces the problem that international migrants represent a very small proportion of the population of a given country and that no survey frame is available ${ }^{3}$. To mitigate these two problems, we applied the same survey method as the one adopted by Lydié, Guilbert, and Sliman (2007) in their survey on Sub-Saharan Africans in Greater Paris. We first used the most recent population censuses in France and Italy to construct three strata according to the density of the Senegalese population in each district. Districts were then randomly drawn within each stratum with probabilities proportional to the number of Senegalese in those districts. We then defined the number of migrants to be surveyed in each selected district using the relative weight of each district in the total Senegalese population ${ }^{4}$. Surveyors were sent in the selected districts and tasked with getting in contact with Senegalese in the public space (streets, markets or shopping centers, metro stations, etc.). To be eligible, interviewees had to meet three criteria: being aged 18 and over; residing in the district; and either being a Senegalese national or a former Senegalese national. Surveyors were also asked to record as much information as possible on those Senegalese migrants who refused to be interviewed. Overall, 579 Senegalese migrants were approached in France among which 300 accepted to be interviewed. If one excludes the sex variable (women being more reluctant than men to be interviewed), no significant difference can be found in terms of age distribution and date of arrival between those who accepted and those who refused to be part of the study. Broadly similar conclusions were reached in the Italian case.

\subsection{Sample Composition and Migrants' Main Characteristics}

Summary statistics on the migrants' characteristics are given in Tables 1 and 2. A striking feature is the difference in migrants' profiles between France and Italy, as suggested by the

\footnotetext{
${ }^{3}$ For a detailed discussion on the difficulties raised by migrant surveys and a comparison of the performance of alternative survey methods, refer to McKenzie and Mistiaen (2009)

${ }^{4}$ Further details on the sampling methodology can be provided by the authors upon request.
} 
tests provided in column (4) of both tables. The population of migrants in Italy appears much more homogeneous with respect to ethnic composition (with a great majority, 77\%, of wolof), religion, since $66 \%$ of them belong to the Murid brotherhood (21\% in France), and geographic origin, with more than one half coming from Dakar. The next most represented regions of origin are Diourbel, Louga and Thies while Senegalese in France come from areas located along the Senegal River, namely Saint-Louis, Matam and Tambacounda. Network effects could explain part of these differentiated patterns, with individuals originating from the same place quite naturally choosing to migrate in the same destination countries. Different measures of migrants' labor market performances are shown in Table 3. We focus the following analysis on remitting behavior and migrant network characteristics.

\section{Migrants' Remitting Behavior}

As reported in Table 4, a remarkable feature of the migration pattern is the high proportion of remittance senders among Senegalese migrants. In the French (Italian) sample, 83.3\% (79.1\%) of them sent remittances either in cash or in kind to Senegal in the last twelve months preceding the survey. Remittances to the origin household are mostly sent on a regular basis, through formal channels and amount to 2,285 euros on average for the pooled sample after excluding non remitters, with a very small and non-significant difference between migrants in France and Italy.

\section{Migrant Networks and Network Services}

The MIDDAS survey has been designed to account for different forms of social capital that may affect migrants' behavior in various ways (family networks, home-town associations, etc.). Family networks are measured by the number of relatives living in France or Italy and the strength of the network inferred from the frequency of the migrant's contacts with his relatives. Survey results show that respectively $64.4 \%$ and $45 \%$ of the migrants in France and Italy had a relative already living in France (Italy) at the time they migrated. At the time they were interviewed, $31.3 \%$ (28.5\%) declared that other members of their origin household were residing in France (Italy), elsewhere than in their own household. Social capital is also measured by the migrants' participation in social, religious, cultural or even sports associations formed by fellow countrymen or home-town members. Respectively $25 \%$ and $48 \%$ of the migrants 
surveyed in France and Italy belong to at least one association, and $19.7 \%$ and $37.1 \%$ to a home-town, community-based or Senegal-related organization. In addition, $15 \%$ of the migrants participate in a rotating savings and credit association (ROSCA) in both countries. Last, surveyed individuals were asked to list the names of the persons they trust and regularly interact with (excluding co-residents) and give their characteristics, such as age, gender, nationality, occupation, family status, as well as information about their relation (how long have they been in contact, how did they meet, how often do they see each other, etc.). The number of listed contacts varies between 0 and 15 . The average network size is 2 and in both countries, more than $55 \%$ of the surveyed migrants name one or two contacts.

Table 5 provides insights on the type of financial and non financial support received by migrants from members of their network. Support to find a job or a place to live is acknowledged by a majority of migrants: respectively $52 \%$ and $45 \%$ declare that they were helped by their family to find a housing at the time they arrived in France and Italy; and $16 \%$ and $8 \%$ still relied on their family to find their current housing. In terms of job access, the support provided by other Senegalese has been key for $25 \%$ of the migrants at the time they arrived in France, and $16 \%$ found their current job thanks to Senegalese acquaintances. The figures are even slightly higher in the case of Italy ( $27 \%$ and $18 \%$ respectively). In addition, $57 \%$ (56\%) of those who experienced periods of unemployment in France (Italy) in the past said received support from family or other Senegalese.

We now turn to a multivariate analysis of the determinants of remittances.

\section{Regression Analysis of Remittance Behavior}

In this section, we empirically explore the determinants of both the likelihood to remit and the amount of remittances using our sample of 602 Senegalese migrants residing in France and Italy. We focus on the effects of networks along three intertwined dimensions, namely access to network services and the nature of those networks, in interaction with the migrants' type. We then discuss our results in the light of other potential alternative interpretations and finally contrast them with other (classical) motives for remittances. 


\subsection{Econometric framework}

In the econometric framework that follows, we basically regress our two dependent variables (the probability to remit on a monthly basis to Senegal and amount remitted) on a set of variables meant to identify our network effects of interest while controlling for the basic characteristics of migrants and recipient households and other main competing motives for remittances.

\subsubsection{Variables definition}

A summary table of all the variables used in the regressions with their definition is provided in Appendix. However, the construction of our network variables calls for further comments. First, note that, even if we are unable in this paper to study the formation of migrant networks and to give a comprehensive view of one particular network ${ }^{5}$, the originality of our dataset lies in the richness of information that has been collected not only on the type of assistance provided by social networks, but also on the characteristics of their members and the nature of the migrant's links with each one of them. This unique feature allows us to address yet largely unexplored issues such as the strength and more generally the quality of the links. Therefore, a contribution of our paper to the empirical analysis of social networks and their impacts is to provide original and refined empirical measures of the strength of network links, and relate them to potentially different economic outcomes, with a focus here on remittance behavior.

In what follows, we adopt a broad definition of migrant networks, the latter being made up of all family, kin or (non family) fellow countrymen a migrant is in contact with. In line with the model sketched in the theoretical discussion, our analysis is centered around three fundamental aspects. As regards the double function of networks, we first try to differentiate network services (the $b$ parameter in the model) from network characteristics that influence the degree of control exerted over the migrant $(\alpha)$, although we are fully aware that both dimensions are intertwined. We also try to take into account the heterogeneity of the migrants as regards their reliance on network services $(\theta)$.

\footnotetext{
${ }^{5}$ Indeed, as we asked each surveyed migrant to list members of his social network, the information collected only reflects for each individual what he unilaterally defines as his own network. The resulting picture is a series of disconnected individual specific networks that are partially observed: each network is reduced to direct links issued from one particular node (representing the position of the migrant in the network).
} 


\section{Network services $\left(b_{i}\right)$}

As proxies for the amount of services provided by the network, we use several dummy variables that equal one if the migrant received help from family members (resp. Senegalese non relatives) to find his first job or housing (0 otherwise); if he received help from family members (resp. Senegalese non relatives) to find his current job or housing (0 otherwise); and if he received help from family members (resp. Senegalese non relatives) during unemployment periods (0 otherwise). Such specifications have two advantages. First, considering different types of assistance provided either upon arrival or in a more recent period allows us to partially rule out endogeneity or simultaneity/reverse causality issues. Second, differentiating between family and non family networks will be particularly useful when we test the predictions of our model against alternative ones derived from other models of remitting behavior (see section 5.3).

As an alternative to those proxies, we also use the information on association membership to create a dummy variable that equals one if the surveyed migrant is member of at least one Senegalese association (i.e. whose members are recruited from the Senegalese community in the country of destination) or Senegal-oriented association (for example promoting the development of localities in Senegal).

\section{Network control $\left(\alpha_{i}\right)$}

As mentioned above, we collected original data on the characteristics of each migrant's personal network. We have detailed information on the basic socio-economic characteristics (age, gender, nationality, education, occupation) of all individuals listed by surveyed migrants when asked to name their close contacts, as well as on the nature of the link itself (how and when they first met, how often they use to see or contact each other). We use these specific pieces of information to construct measures of the "quality" of the network, or "strength" of network links and use these variables as proxies for the degree of control network members may exert over one another.

We first use the size of the network (the number of listed contacts) and variables describing its composition: number of relatives, kinship members and/or fellow countrymen originating from the same community in Senegal, number of Senegalese, and number of older members (at least ten years older than the respondent). We expect these variables to positively affect remittances 
by enhancing the network's capacity to monitor the migrant through various channels. First a larger network is likely to have access to more information and to better detect deviant behavior. Second, relatives and migrants originating from the same community are likely to have frequent contacts with most recipient households, so that information on one migrant's behavior may be expected to circulate easily. Last, as suggested by the anthropological literature, significant age differentials between network members are likely to matter: senior migrants are expected to advocate traditional values and encourage younger migrants to commit to their obligations ${ }^{6}$.

We also use information on the geographical distance between the migrant and the members of his network (as measured by travel time) and on the frequency of contacts between them to construct network strength indices. We do so by re-weighting each network member by his (physical or virtual) proximity. The shorter the geographical distance, the better the capacity to monitor and detect deviant behaviors, the higher the weight.

\section{Network valuation $\left(\theta_{i}\right)$}

The way each migrant values network services is a rather subjective notion, hard to accurately assess through our (if not any) migrant survey. The need of or reliance on network resources could actually be proxied by various variables such as migration duration, education, social insertion in the destination country, type of education (koranic or not for instance) or religious beliefs especially in the Senegalese context. However, we expect such crude measures to allow for alternative interpretations and particularly to capture altruism or migrants' loyalty to their origin household or country, in a sense that may confound our results if they happen to be correlated with both remittances and network insertion (see section 5.3). As a consequence, we chose to focus on one specific dimension of network valuation which is linked to migrants' precariousness on the labor market. Indeed, we use as a proxy a dummy for job insecurity or unemployment equal to one if the migrant has an insecure job (either because he has a shortterm or seasonal job, an undeclared job or a job without contract), or if he is unemployed at the time of the survey. The underlying intuition is that those insecure migrants are more likely to value community membership and network resources, since they are also those who might need assistance and insurance the most.

\footnotetext{
${ }^{6}$ Conversely, if migrants were to collude against their origin households, which is very unlikely, such a behavior should be facilitated by age proximity
} 


\subsubsection{Basic specifications}

Before describing the specification of our econometric models, we have to acknowledge that we lack a suitable identification strategy, despite using a unique but small cross-section dataset. Indeed, we observe simultaneously the specific position of some migrants in their network as well as the occurrence and amount of remittances they sent at a given point in time, so that we are unable to uncover any dynamics in migrants' decisions. Furthermore, as suggested by our theoretical discussion, both outcomes are intertwined and simultaneously determined. However, we could find no credible instruments, that is to say variables that affect the characteristics and use of network resources by a migrant independently of the amount of remittances he sends. Therefore, the cross-sectional data we use do not allow anyway to identify any indisputable causal effect. Nonetheless, in line with our theoretical model, we try to put forward some robust correlations between network characteristics and remittance behavior, controlling for a whole set of migrant and recipient household characteristics intended to rule out alternative interpretations and purge the effects of competing remittance motives.

We first model the discrete decision on whether to remit on a regular basis or not ${ }^{7}$ using both Linear Probability Models (LPM) and Probit models. ${ }^{8}$ We then model the decision on how much to remit using both OLS and Tobit models in order to account for non-remitters:

The equation to be estimated writes:

$$
R_{i}=\beta_{1}+\beta_{2} X_{i}+\beta_{3} X_{h}+\beta_{4} \theta_{i}+\beta_{5} b_{i}+\beta_{6} \alpha_{i}+\beta_{7} \theta_{i} \cdot b_{i}+\beta_{8} \theta_{i} \cdot \alpha_{i}+\epsilon_{i}
$$

where $R_{i}$ is alternatively a dummy equal to 1 if migrant $i$ sent monthly remittances in cash or kind to any household in Senegal over the past 12 months and the observed amount of remittances in cash or in kind sent by migrant $i$ over the past 12 months. $b_{i}$ and $\alpha_{i}$ are the network variables of interest for migrant $i$ and , $\theta_{i}$ is the variable measuring migrant's $i$ valuation of network services. In the analysis that follows, our focus is actually on the interaction terms of

\footnotetext{
${ }^{7}$ We tried two alternative specifications for the dependent variable in the discrete model: the likelihood to remit and the likelihood to remit on a monthly basis. Most regression results were very similar, but since the great majority of sample migrants sends remittances, we decided to focus on the second specification to get higher variance in the dependent variable and increase confidence in our statistical analysis. Regression results using the first specification are available upon request.

${ }^{8}$ Though Probit models are more suited to binary dependent variables and Tobit models to limited dependent variable, we also chose to run LPM and OLS regressions for at least two reasons. First, we are mainly interested in estimating the sign of any relevant and significant correlations. Second, inference based on estimated coefficients on interaction terms in nonlinear models is not direct, as shown by Ai and Norton (2003)
} 
those variables, $\theta_{i} \cdot b_{i}$ and $\theta_{i} \cdot \alpha_{i}$. We indeed expect those interaction terms to be significant, since a higher amount of services expected from the network and/or a higher control translating into a higher risk of being punished and deprived of network resources are both likely to constitute stronger incentives to remit for those migrants who strongly need or rely on network services. $X_{i}$ and $X_{h}$ are a set of migrant $i$ 's and main recipient household $h$ 's characteristics that are likely to jointly affect remittance behavior. As emphasized in the theoretical discussion, the model is general enough to encompass some of the more classical remittance motives encountered in the theoretical and empirical literature. Thus, in order to assess the relevance of those motives in our context and rule out alternative interpretations that may drive our results, we include in this vector, together with basic controls for migrants' age (and its square), gender and income (and its square), the following variables: the number of years spent in the destination country, dummies for education level, a dummy for koranic schooling, a dummy for the migrant's intention to return and settle in Senegal, a wealth index for the recipient household, a dummy for whether the recipient household resides in a rural area, a dummy for the presence of the migrant's spouses and/or children in the recipient household and the number of other members of the recipient household currently in migration ${ }^{9}$. Note that most of these variables are likely to capture different effects and may be interpreted differently according to which remittance motive is expected to matter most. Their effects will be discussed in section 5.3. Last, $\epsilon_{i}$ is an individual error term

All the above regressions are run on the pooled sample as well as on French and Italian subsamples, in order to additionally uncover differential patterns according to the country of destination. A control for the country of residence (a dummy that equals one for migrants residing in Italy) is included in all the regressions run on the pooled sample.

\subsection{Results}

In this section, we focus on the parameter estimates relating to our network variables. The discussion and interpretation of the other regression results as well as robustness checks are provided in the next section.

Table 6 reports the results from estimations of the propensity to remit on a regular basis on

\footnotetext{
${ }^{9}$ See table 12 in Appendix for a detailed description of the variables
} 
the pooled sample and separate samples for France and Italy. ${ }^{10}$

Whatever the specification and sample, we find no direct correlation between our network variables and the propensity to remit: none of the coefficients of our measures of network services are indeed significant. In addition, migrants' reliance on the network as measured by their situation in the labor market is found to negatively affect their propensity to remit on a regular basis. At first sight, these results challenge our theoretical assumptions. However, when the effect of the network variables is allowed to differ between migrants depending on how they value (or rely on) network services, our regression results lead to quite different conclusions (Tables 7 and 8). Indeed, when interaction terms are added to the set of regressors, we find that those migrants in precarious working conditions who have ever benefited from network services do not show lower propensity to remit than more secure migrants and are even more likely to remit regularly (as suggested by the significance of the interacted terms). By contrast, those insecure migrants who never got help from their network are found to be less likely to remit. The same results are obtained for job-insecure migrants with large and dense networks (Table 8). The larger the network, or the better its capacity to monitor the migrant's behavior (as measured for e.g. by the network strength index or the presence of senior migrants in the network), the higher the propensity to remit on a regular basis.

The regression results from our estimations on remitted amounts (Tables 9, 10 and 11) exhibit a similar and even more robust pattern ${ }^{11}$. Here again, we find no significant correlation between our network variables and remitted amounts. Moreover, insecure migrants who never benefited from network assistance or those who are not inserted in large and dense networks, are found to remit lower amounts on average. However, interactions terms between our network variables and our measure of the migrants' reliance on the network are all significant and positive, apart from interacted terms computed with family networks. Controlling for income and its square, insecure migrants who ever benefited from the help of non-family networks or have larger and denser network, are thus found to remit more than insecure migrants who were never helped or do not have large networks. More surprisingly, they are found to remit at least as much and very likely more than migrants with less precarious working conditions. All those results are consistent with our theoretical framework: network services provide an overall

\footnotetext{
${ }^{10}$ Regression models in which the dependent variable is the propensity to remit either regularly or irregularly provide very similar results that are available upon request

${ }^{11}$ This is partly due to the greater variance observed in remitted amounts.
} 
incentive to remit, but migrants' heterogeneity matters. Indeed, the incentive effect of network services is stronger for those migrants who value network resources the most. Remittances can thus be seen as a fee that migrants pay to have a granted access to network-based assistance, a fee that is only paid by those migrants who are more likely to be in need of such network-based assistance.

Additional results on the social control dimension of networks (Table 11) suggest that it is not only networks services that matter per se, but rather their ability and efficiency in monitoring the migrant's behavior. Here again, the threat of being punished is more effective among those migrants who are more in need of network resources.

The contrasted results found for family networks call for additional comments. Indeed, the negative sign of the coefficient on the interaction terms computed with family networks is not in line with our theoretical framework and is somewhat puzzling. Two interpretations can actually be put forward based on the observation that the two types of network assistance (that provided by family members on the one hand, and that provided by Senegalese non relatives on the other hand) seldom overlap. First, such a result could be driven by the fact that most migrants relying on family help are not pioneer migrants: the majority of them are indeed new links in the family migration chain, which suggests that their origin households have an old tradition of migration. They may as such be less reliant on each migrant's remittances (since the financial burden of taking care of those left behind is likely to be shared between several migrants) or senior migrants (or those with secure working conditions) may accept to fully support the burden. Second, migrants who were helped by family members in the destination country may be repaying them. In such a case, that would alter their capacity to remit to those left behind, in Senegal.

Before turning to the other variables, note that all our results hold when the same regressions are run on each country's sample (due to space limitations, tables are not reported here but are available upon request). Coefficients are of similar magnitude and show similar signs. However, their significance is mostly driven by the French sample. 


\subsection{Robustness checks}

The previous section put forward significant correlations between remittance behavior, especially remitted amounts, and migrant networks' characteristics. Results are robust across most measures of networks resources and (monitoring) capacity. The aim of this last section is to rule out potential alternative interpretations for our estimated effects and assess the contribution of other competing remittance motives that may drive our results.

\subsubsection{Alternative interpretations}

As briefly mentioned in our theoretical discussion, (partially unobserved) altruism, and more generally loyalty and attachment to the community and country of origin may challenge our main assumption. Indeed, if altruistic and loyal migrants happen to belong to larger and more efficient networks and to remit more frequently (as well as to send higher amounts), failing to take this effect into account might induce a spurious correlation between our network variables and remittances, due to a classical omitted variable bias. Another related concern is the internalization of solidarity norms by migrants that would equally lead them to exhibit higher network valuation and to remit more.

Yet, if our network measures were only capturing the strength of the migrants' links with their origin country and their willingness to remit more, we should observe a positive direct correlation between our network variables and remittances. This is actually not what we find: whatever the specification, none of the coefficients of the network variables is significantly different from zero (and some of them even show a negative sign). Only interaction terms are found to be significant, which suggests that, in line with our theoretical setting, the extent to which migrants value network services do matter. We could find no credible reason why our job insecurity proxy would be correlated with altruism or loyalty (once other basic characteristics are controlled for).

However, in order to definitely rule out the possibility that our results could be driven by unobserved altruism, we estimate a bivariate Probit model in which the two dependent variables are the propensity to remit $\left(R_{i}\right)$ and a dummy variable for having access to network services 
$\left(b_{i}\right)^{12}$. This model is indeed well-suited to the theoretical framework we chose, since we consider the migrants as being faced with a joint choice of accessing to network resources and paying a tax on their income through remittances. In addition, the bivariate Probit specification allows error terms in both equations to be correlated, and thus allows for potential migrants' unobservable characteristics to explain both their remitting behavior and their network insertion. Results on the pooled sample are given in Table 13 in Appendix (results hold on French and Italian samples but are not shown here). Note that the test for the correlation between the error terms in both equations is not significant. Such a finding can accept two interpretations. First, our theoretical assumption according to which some common characteristics would drive the migrants' access to network services and their remitting behavior may not be an adequate representation of the migrants' behavior since those two outcomes do not happen to be as much correlated as expected.

A second interpretation is that the explanatory variables that were selected to enter both equations constitute good enough proxies for the migrants' degree of loyalty or attachment to their origin country so that no unobservable component remains since unobservable characteristics driving both choices would imply a positive correlation between the error terms. In other words, the absence of correlation between residuals, added to the fact that the signs of most coefficients differ in both equations, seem to rule out our concern about omitted variable bias.

Even if it does not fully address the issue of causality since both outcomes are simultaneously determined, we are confident that our estimated effects are not entirely driven by a pure altruism/loyalty effect and in line with our network interpretation.

Another alternative interpretation that may challenge our network story is that our job insecurity variable is not a correct proxy for valuation of network services but may rather be interpreted as an incentive for migrants to remit because they intend to return soon and settle in Senegal. In other words, the precariousness of their situation in the labor market may induce migrants to remain closely connected to their community in order to secure a "comfortable" return to their home country. We control for this plausible effect by introducing

\footnotetext{
${ }^{12}$ The two estimated equations write as follows:
}

$$
\left\{\begin{aligned}
R_{i} & =\beta_{1}+\beta_{2} X_{i}+\beta_{3} X_{h}+\beta_{4} \theta_{i}+\epsilon_{i, 1} \\
b_{i} & =\beta_{5}+\beta_{6} X_{i}+\beta_{7} X_{h}+\beta_{8} \theta_{i}+\epsilon_{i, 2}
\end{aligned}\right.
$$

where variables are defined as above. Both equations are estimated simultaneously and individual error terms $\epsilon_{1, i}$ and $\epsilon_{2, i}$ are allowed to be correlated 
in our regressions a dummy variable for whether the migrant intends to return (0 otherwise). As expected, its coefficient is positive in most specifications but never significant. Furthermore, it does not drive out the results on most of our network variables.

One other major concern relates to the potential endogeneity and simultaneous/reverse causality issues regarding our different network variables, and especially our interacted terms between labor market outputs and network resources. More precisely, it may be the case that those migrants who benefited from network-based assistance or insurance have de facto better job status and get higher incomes, so that they are more able to fulfill their remittance obligations. Conversely, insecure migrants may be more likely to be inserted in networks, since they need its resources the most. Last, efficient networks may temporarily help migrants send remittances in times of hardship. Overall, such interpretations challenge our story of remittances as being a fee that precarious migrants pay to secure their access to network services.

Four elements partially rule out these alternative stories. First, note that, whatever the specification, a measure of the migrant's income that includes social benefits and transfers is included in the set of regressors. Second, our results are robust to various definitions of network services, and especially when we only use information on help upon arrival, help to find housing and particularly past help to find first housing. Past use of network services related to housing may indeed be less subject to endogeneity concerns since they are less related to the migrants' (current) income than help to find a job, and less affected by reverse causality issues than help to get current housing or job. Third, controlling for basic migrant characteristics, we could find no significant correlation between current job status or unemployment, and past network services (not shown here). Last, while it is true that a broader network (as measured by the size of the network) could just capture ability to remit rather than incentive to remit in times of hardship, this is less clear for some of our alternative measures. As an illustration, the network strength index, which is computed as the average distance between migrants and network members in travel time and is thus a good proxy for monitoring costs is unlikely to be correlated with the capacity of the network to financially support the migrant.

A caveat with the previous discussion is that a last alternative interpretation would consist in considering that migrants having benefited from network services in the past would remit today in order to repay for these services. Nonetheless, if remittances were driven by a variant of the 
loan repayment motive, we would expect direct coefficients on past help to be significant, which again is not the case (only interactions with network valuation are). We would additionally expect amounts to be at least as much correlated (not to say more) with services provided by family members as with the ones provided by non-family members. However, a striking result is that network variables involving only family members do affect neither the probability to remit, nor remitted amounts (or even negatively for insecure migrants). We only observe positive correlations with non-family network help. If the latter correlation is to be interpreted as a loan repayment, it implies that loans by non-family network are paid back to recipient households. Such an interaction where the exchange of services between a migrant and his recipient household is mediated by the network is thus fully consistent with our theoretical framework.

\subsubsection{Other remittance motives}

Since the previous sections were especially focused on assessing the relevance of the effect of our network variables with regards to our theoretical model, we now turn to the interpretation of the other results in the light of competing motives for remittances.

\section{Altruism}

To be properly tested, the main prediction of altruistic models requires having precise measures of the senders' income and recipients' pre-transfer income. In our case, the propensity to remit and remitted amounts are found to be positively correlated with the migrants' income. For lack of information on (pre-transfer) recipient households' income, we use a score of household wealth as our main proxy. While the positive sign for this variable is in contradiction with the altruism hypothesis, altruistic motives may still be at play if current household wealth is partly explained by past remittances (and is thus endogenous). The positive correlation between remittances and household wealth could also partially reflect information asymmetries and the migrants' biased estimation of remote households' wealth. Besides, we find that those migrants who rank their origin household among the poorest of their village community are more likely to remit (not shown here).

The negative impact of migration duration on the propensity to remit for migrants in France is also in line with the predictions of altruistic models (altruism is acknowledged to fade over 
time $)^{13}$, while the opposite result using the Italian sample is more puzzling and might be interpreted as an income or wealth effect not fully captured by our set of regressors. It may also be the mere result of different time patterns of migration flows in both countries. As expected, close family ties with members of the recipient household, and particularly spouses or children living in Senegal, are positively and significantly correlated with both the propensity to remit and the level of remittances.

However, as discussed above, the absence of correlation between residuals in the bivariate Probit model may be seen as evidence that our variables measuring the migrants' altruism or their internalization of solidarity norms, namely Koranic schooling or time spent abroad among others, are good enough proxies that control for their potential confounding effect in our setting.

In conclusion, we cannot exclude that some altruism may drive the remittance behavior of Senegalese migrants, but altruism cannot satisfactorily account for the correlations involving our network variables of interest.

\section{Exchange of services}

Some of the variables that could be involved in the altruism motive may also reflect an exchange motive, other than the variant we propose in this paper. For instance, it could be argued that migrants with spouses or children living in Senegal remit more often and send higher amounts because remittances are the price to be paid for their relatives to be taken care of. Again, this motive may be effective but is not likely to drive our results on networks.

\section{Inheritance}

In order to control for this specific motive, we first included in the regression a dummy that equals one if the migrant is the son or daughter of the recipient household head ( 0 otherwise). This variable does not affect the propensity to remit nor remitted amounts, which suggests that the inheritance motive plays no significant role in this setting. We also included the number of other migrants from the same origin household. In the Italian case, this variable is in some specifications positively correlated with the propensity to remit, which could be consistent with inheritance incentives, although remitted amounts are not found to be affected. ${ }^{14}$

\footnotetext{
${ }^{13}$ Another interpretation in line with our theoretical framework would be that this effect captures decreasing needs of network resources when migrants have settled abroad for a long time

${ }^{14}$ We further tested the inheritance motive by adding an interaction between intention to return and recipient household wealth. We found a significant positive coefficient on this variable, which is consistent with the
} 


\section{Insurance}

We collected information on the migrant's perception of shocks having affected his recipient household in the last 5 years, and used this variable in our regressions to test for the insurance motive. We find no such evidence, since neither negative nor positive shocks are found to be correlated with remittances (not shown here). Moreover, a large majority (72\%) of migrants who remit do so on a regular basis, which partially contradicts the insurance story.

\section{Investment and loan repayment}

Our data provides no clear evidence of the investment motive. If remittances were repaying the household for investment in the migrant education, we would expect migrants with higher levels of education to remit more, which is not what we find. Indeed, neither the propensity to remit nor remitted amounts are significantly affected by our education dummies. By contrast, the strong significance of the koranic schooling variable brings support to the idea that this variable captures something else. As suggested above, we interpret it as the effect of the internalization of solidarity norms, conveyed by the Islamic religion.

As for loan repayment, and especially repayment of migration costs, no evidence emerge and alternative variables that we computed using information collected on the origin of funds used to cover migrants' travel and expenses are not correlated with the probability to remit, nor remitted amounts (not shown here).

On the whole, all these results suggest that some of the "classical" remittance motives may be effective in our setting. What we contend in this paper is that they are unable to fully explain the wide variety of remittance behaviors. Moreover, they do not rule out and cannot account for the network incentive motive we put forward.

\section{Conclusion}

This paper invests a neglected area in the study of the determinants of migrants' remittances to their origin household. Indeed, if one excludes the few studies by socio-anthropologists, no paper has explicitly assessed the role of migrant networks in migrants' remitting behavior. Our aim in this paper is thus to explore this issue both theoretically and empirically using original

inheritance motive. However, since it did not alter our results on network variables, we decided not to keep this variable in the final set of regressors 
data on Senegalese migrants that we collected in France and Italy in 2009.

We start with a theoretical discussion of remittance motives and the way migrant networks could fit into existing theoretical models. We then propose a very simple and general model in which we account for the double function of migrant networks as providers of services or assistance to their members, but also as conveyors of information between home and host countries. Thanks to (or because of) this double function, we argue that migrant networks may be used by household members in the home country to control a substantial share of migrants' monetary resources. The classical principal (household) - agent (migrant) model we develop is based on the assumption that the migrant population is heterogeneous, with some migrants valuing more (or being in greater need of) network resources than others. The household's ability to extract the migrant's information rent (on his capacity to remit as measured by his income) is assumed to depend in particular on the efficiency of the network in collecting and spreading information and on its ability to punish deviant migrants.

We then proceed exploring whether these predictions are consistent with empirical evidence. To this end, we use an original dataset of 602 Senegalese migrants living either in France or Italy. The results from our multivariate analyses, while not challenging those from previous studies of the determinants of remittances, suggest that network characteristics additionally play a non negligible role in explaining migrants' transfer behavior. Migrants are indeed found to be more likely to remit and remit significantly more when they are expected to value more network services and/or when the efficiency of the network in providing resources and exerting control tends to be higher.

Obviously, one should be very careful to draw strong and definitive conclusions from these findings. The empirical evidence, although fully consistent with our theoretical model, is based both on a small sample of migrants and on cross-sectional data which makes it difficult to deal adequately with unobserved heterogeneity. However, this paper is an original attempt to conceptualize the way family and kinship ties may affect individuals' transfer behavior in the context of a community of migrants. Remittances may indeed be, in part, the price for access to network facilities. Implications in terms of welfare remain however an open question that is left for further investigations. 
Tables 
Table 1: Migrant main characteristics

\begin{tabular}{|c|c|c|c|c|}
\hline & $\begin{array}{c}(1) \\
\text { France } \\
(\%)\end{array}$ & $\begin{array}{c}(2) \\
\text { Italy } \\
(\%)\end{array}$ & $\begin{array}{c}(3) \\
\text { Total } \\
(\%)\end{array}$ & $\begin{array}{c}(4) \\
\operatorname{Diff}(\mathbf{1})-(2)^{(a)}\end{array}$ \\
\hline Male & 75.7 & 77.2 & 76.4 & \\
\hline $\begin{array}{l}\text { Age groups } \\
18-25 \text { years } \\
25-35 \text { years } \\
35-45 \text { years } \\
45-60 \text { years } \\
60-75 \text { years }\end{array}$ & $\begin{array}{r}11.0 \\
35.7 \\
28.3 \\
22.0 \\
3.0\end{array}$ & $\begin{array}{r}9.6 \\
33.8 \\
39.7 \\
16.9 \\
0.0\end{array}$ & $\begin{array}{r}10.3 \\
34.7 \\
34.1 \\
19.4 \\
1.5\end{array}$ & $\begin{array}{l}* * * \\
* * *\end{array}$ \\
\hline $\begin{array}{l}\text { Schooling } \\
\text { No schooling } \\
\text { Elementary school } \\
\text { Middle school } \\
\text { High school } \\
\text { Vocational } \\
\text { University }\end{array}$ & $\begin{array}{r}18.0 \\
18.0 \\
16.3 \\
14.3 \\
8.3 \\
25.0\end{array}$ & $\begin{array}{r}10.9 \\
12.3 \\
25.2 \\
18.9 \\
6.3 \\
26.5\end{array}$ & $\begin{array}{r}14.5 \\
15.1 \\
20.8 \\
16.6 \\
7.3 \\
25.8\end{array}$ & $\begin{array}{l}* * \\
* * \\
* * *\end{array}$ \\
\hline $\begin{array}{l}\text { Last grade completed } \\
\text { None } \\
\text { CEP } \\
\text { BEPC } \\
\text { CAP/BEP } \\
\text { Bac/brevet } \\
\text { Undergraduate } \\
\text { University }\end{array}$ & $\begin{array}{r}31.7 \\
18.3 \\
11.3 \\
7.0 \\
9.0 \\
6.3 \\
16.3\end{array}$ & $\begin{array}{r}15.6 \\
15.6 \\
22.5 \\
8.0 \\
17.6 \\
11.6 \\
9.3\end{array}$ & $\begin{array}{r}23.6 \\
17.0 \\
17.0 \\
7.5 \\
13.3 \\
9.0 \\
12.8\end{array}$ & $\begin{array}{l}* * * \\
* * * \\
* * * \\
* * \\
* * *\end{array}$ \\
\hline $\begin{array}{l}\text { Type of schooling } \\
\text { None } \\
\text { Koranic only } \\
\text { Formal only } \\
\text { Both koranic and formal }\end{array}$ & $\begin{array}{r}2.7 \\
15.3 \\
17.3 \\
64.7\end{array}$ & $\begin{array}{r}1.7 \\
9.3 \\
11.9 \\
77.2\end{array}$ & $\begin{array}{r}2.2 \\
12.3 \\
14.6 \\
70.9\end{array}$ & $\begin{array}{c}* * \\
* \\
* * *\end{array}$ \\
\hline $\begin{array}{l}\text { Ethnic group } \\
\text { Wolof } \\
\text { Peul } \\
\text { Soninke }\end{array}$ & $\begin{array}{l}27.3 \\
25.0 \\
19.7\end{array}$ & $\begin{array}{r}77.8 \\
8.3 \\
0.7\end{array}$ & $\begin{array}{l}52.7 \\
16.6 \\
10.1\end{array}$ & $\begin{array}{l}* * * \\
* * * \\
* * *\end{array}$ \\
\hline $\begin{array}{l}\text { Religion (brotherhood) } \\
\text { Murid }\end{array}$ & 20.7 & 66.2 & 43.5 & $* * *$ \\
\hline $\begin{array}{l}\text { Region of origin } \\
\text { Dakar } \\
\text { Thies } \\
\text { Diourbel } \\
\text { Fatick } \\
\text { Kaolack } \\
\text { Louga } \\
\text { Saint-Louis } \\
\text { Matam } \\
\text { Ziguinchor } \\
\text { Kolda } \\
\text { Tambacounda } \\
\text { Other country } \\
\text { Unknown }\end{array}$ & $\begin{array}{r}48.7 \\
7.7 \\
2.3 \\
1.0 \\
2.7 \\
0.7 \\
2.0 \\
6.0 \\
6.0 \\
3.3 \\
16.0 \\
1.7 \\
2.0\end{array}$ & $\begin{array}{r}56.0 \\
10.9 \\
11.3 \\
0.7 \\
4.3 \\
10.3 \\
2.3 \\
0.7 \\
0.7 \\
0.7 \\
0.7 \\
0.3 \\
1.3\end{array}$ & $\begin{array}{r}52.3 \\
9.3 \\
6.8 \\
0.8 \\
3.5 \\
5.5 \\
2.2 \\
3.3 \\
3.3 \\
2.0 \\
8.3 \\
1.0 \\
1.7\end{array}$ & $\begin{array}{l}* * * \\
* * * \\
* * * \\
* * \\
* * * \\
* *\end{array}$ \\
\hline Observations & 300 & 302 & 602 & \\
\hline
\end{tabular}


Table 2: Migrant's situation in host country

\begin{tabular}{|c|c|c|c|c|}
\hline & $\begin{array}{c}(1) \\
\text { France } \\
(\%)\end{array}$ & $\begin{array}{c}(2) \\
\text { Italy } \\
(\%)\end{array}$ & $\begin{array}{c}(3) \\
\text { Total } \\
(\%)\end{array}$ & $\begin{array}{c}(4) \\
\operatorname{Diff}(1)-(2)\end{array}$ \\
\hline $\begin{array}{l}\text { Place of residence } \\
\text { Main cities }\end{array}$ & 72.3 & 48.0 & 60.1 & $* * *$ \\
\hline $\begin{array}{l}\text { Type of household } \\
\text { Alone } \\
\text { With spouse and/or children } \\
\text { With other relatives or friends }\end{array}$ & $\begin{array}{l}39.3 \\
34.7 \\
26.0\end{array}$ & $\begin{array}{l}14.2 \\
35.4 \\
50.3\end{array}$ & $\begin{array}{l}26.7 \\
35.1 \\
38.2\end{array}$ & $\begin{array}{l}* * * \\
* * *\end{array}$ \\
\hline $\begin{array}{l}\text { Household size } \\
1 \\
2 \\
3 \\
4 \\
5 \\
\text { More than } 5\end{array}$ & $\begin{array}{r}39.3 \\
25.3 \\
13.3 \\
7.3 \\
5.0 \\
9.7\end{array}$ & $\begin{array}{r}14.2 \\
20.2 \\
28.1 \\
20.5 \\
8.6 \\
8.3\end{array}$ & $\begin{array}{r}26.7 \\
22.8 \\
20.8 \\
14.0 \\
6.8 \\
9.0\end{array}$ & $\begin{array}{l}* * * \\
* * * \\
* * *\end{array}$ \\
\hline $\begin{array}{l}\text { Date of arrival } \\
\text { Born here or arrived aged under } 15 \\
\text { Arrived before } 1990 \\
\text { Arrived between } 1990 \text { and } 2000 \\
\text { Arrived After } 2000\end{array}$ & $\begin{array}{r}9.0 \\
21.0 \\
23.7 \\
46.3\end{array}$ & $\begin{array}{r}2.3 \\
11.6 \\
32.5 \\
53.6\end{array}$ & $\begin{array}{r}5.7 \\
16.3 \\
28.1 \\
50.0\end{array}$ & $\begin{array}{c}* * * \\
* * * \\
* * \\
*\end{array}$ \\
\hline $\begin{array}{l}\text { Type of documents } \\
\text { Tourist visa } \\
\text { Work permit } \\
\text { Family reunification } \\
\text { Other visa (including student) }\end{array}$ & $\begin{array}{r}31.4 \\
4.5 \\
14.7 \\
46.9\end{array}$ & $\begin{array}{r}56.3 \\
5.6 \\
16.0 \\
19.1\end{array}$ & $\begin{array}{r}44.8 \\
5.1 \\
15.4 \\
31.9\end{array}$ & $* * *$ \\
\hline $\begin{array}{l}\text { Social networks } \\
\text { Member of at least one Senegal related association } \\
\text { Average size of close network } \\
\text { Kin in close network } \\
\text { Senegalese only network } \\
\text { Older (at least } 10 \text { years) members in close network }\end{array}$ & $\begin{array}{r}19.7 \\
2.1 \\
47.7 \\
57.3 \\
15.2\end{array}$ & $\begin{array}{r}37.1 \\
1.8 \\
35.1 \\
58.9 \\
12.9\end{array}$ & $\begin{array}{r}28.4 \\
2.0 \\
41.3 \\
58.1 \\
14.1\end{array}$ & $\begin{array}{l}* * * \\
* * *\end{array}$ \\
\hline Observations & 300 & 302 & 602 & \\
\hline
\end{tabular}

Source: MIDDAS Survey, 2009

(a) Test for equality of the two columns: *** indicates $1 \%$ significance level, ${ }^{* *} 5 \%$ significance level level and * $10 \%$ significance level 
Table 3: Migrant's labor status and income

\begin{tabular}{|c|c|c|c|c|}
\hline & $\begin{array}{c}(1) \\
\text { France } \\
(\%)\end{array}$ & $\begin{array}{c}(2) \\
\text { Italy } \\
(\%)\end{array}$ & $\begin{array}{c}(3) \\
\text { Total } \\
(\%)\end{array}$ & $\begin{array}{c}(4) \\
\operatorname{Diff}(\mathbf{1})-(2)^{(a}\end{array}$ \\
\hline \multicolumn{5}{|l|}{ Labor status } \\
\hline Regularly employed & 73.0 & 68.9 & 70.9 & \\
\hline Occasionally employed & 4.0 & 2.6 & 3.3 & \\
\hline Unemployed & 14.3 & 20.9 & 17.6 & $* *$ \\
\hline Inactive & 6.3 & 4.0 & 5.1 & $* *$ \\
\hline N.R & 2.3 & 3.6 & 3.0 & \\
\hline Observations & 300 & 302 & 602 & \\
\hline \multicolumn{5}{|l|}{ Employment status } \\
\hline N.R & 0.5 & 0.5 & 0.5 & \\
\hline Unpaid family members & 0.5 & 1.4 & 0.9 & * \\
\hline Self-employed/Entrepreneur & 13.7 & 25.5 & 19.4 & $* * *$ \\
\hline Wage workers & 85.4 & 72.6 & 79.2 & $* * *$ \\
\hline Permanent contract & 62.6 & 58.9 & 60.9 & \\
\hline Fixed-term contract & 19.3 & 16.6 & 18.0 & \\
\hline Temporary/Interim & 11.2 & 7.3 & 9.5 & \\
\hline Apprenticeship & 2.1 & 0.7 & 1.5 & \\
\hline Informal/No contract & 4.3 & 13.9 & 8.6 & \\
\hline N.R & 0.5 & 2.6 & 1.5 & \\
\hline \multicolumn{5}{|l|}{ Socio-economic classification } \\
\hline Lower technical & 45.7 & 50.0 & 47.8 & \\
\hline Lower services, sales and clerical & 28.8 & 7.2 & 18.3 & $* * *$ \\
\hline Intermediate & 6.4 & 3.4 & 4.9 & \\
\hline Small employers and self-employed & 0.0 & 24.0 & 11.7 & $* * *$ \\
\hline Large employers, higher grade professional, managerial & 5.5 & 1.9 & 3.7 & \\
\hline Other & 11.9 & 10.1 & 11.0 & \\
\hline N.R & 1.8 & 3.4 & 2.6 & \\
\hline \multicolumn{5}{|l|}{ Wage categories } \\
\hline less than 500 euros & 3.2 & 9.1 & 6.1 & * \\
\hline 500 to 1000 euros & 22.4 & 23.6 & 23.0 & \\
\hline 1000 to 1250 euros & 26.5 & 28.8 & 27.6 & \\
\hline 1250 to 1500 euros & 17.8 & 14.9 & 16.4 & \\
\hline 1500 to 2000 euros & 17.8 & 9.1 & 13.6 & * \\
\hline 2000 to 2500 euros & 4.6 & 0.5 & 2.6 & ** \\
\hline 2500 to 3000 euros & 0.5 & 2.4 & 1.4 & ** \\
\hline 3000 to 5000 euros & 2.7 & 1.0 & 1.9 & \\
\hline 5000 to 8000 euros & 0.5 & 0.0 & 0.2 & \\
\hline N.R & 4.1 & 10.6 & 7.3 & \\
\hline Observations $^{(b)}$ & 219 & 208 & 427 & \\
\hline
\end{tabular}

Source: MIDDAS Survey, 2009

(a) Test for equality of the two columns: $* * *$ indicates $1 \%$ significance level, ${ }^{* *} 5 \%$ significance level level and $* 10 \%$ significance level

(b) Regularly employed migrant only 
Table 4: Remittance behavior

\begin{tabular}{|c|c|c|c|c|c|c|}
\hline & \multicolumn{2}{|c|}{ France } & \multicolumn{2}{|c|}{ Italy } & \multicolumn{2}{|c|}{ Total } \\
\hline & mean & sd & mean & sd & mean & sd \\
\hline \multicolumn{7}{|c|}{ Remittances to any household } \\
\hline - In $\operatorname{cash}(\%)$ & 76.0 & $(-)$ & 62.3 & $(-)$ & 69.1 & $(-)$ \\
\hline - Total amount in euros & 2277 & $(2024)$ & 2551 & $(1983)$ & 2401 & $(2008)$ \\
\hline - In cash or kind (\%) & 83.3 & $(-)$ & 79.1 & $(-)$ & 81.2 & $(-)$ \\
\hline - Total amount in euros & 2338 & $(2063)$ & 2594 & $(2051)$ & 2454 & $(2059)$ \\
\hline \multicolumn{7}{|c|}{ Remittances to the origin household } \\
\hline - In cash $(\%)$ & 75.3 & $(-)$ & 59.9 & $(-)$ & 67.6 & $(-)$ \\
\hline - Total amount in euros & 2117 & $(1941)$ & 2373 & $(1930)$ & 2232 & (1938) \\
\hline - In cash or kind (\%) & 75.3 & $(-)$ & 60.3 & $(-)$ & 67.8 & $(-)$ \\
\hline - Total amount in euros & 2177 & $(1979)$ & 2420 & $(2002)$ & 2285 & $(1990)$ \\
\hline Observations $^{(a)}$ & \multicolumn{2}{|c|}{300} & \multicolumn{2}{|c|}{302} & \multicolumn{2}{|c|}{602} \\
\hline \multicolumn{7}{|c|}{ Frequency of money transfers (\%) } \\
\hline Monthly & 50.4 & $(-)$ & 66.2 & $(-)$ & 58.3 & $(-)$ \\
\hline Bimonthly & 7.4 & $(-)$ & 4.5 & $(-)$ & 5.9 & $(-)$ \\
\hline Quarterly & 4.2 & $(-)$ & 0.3 & $(-)$ & 2.2 & $(-)$ \\
\hline Annually & 0.3 & $(-)$ & 0.3 & $(-)$ & 0.3 & $(-)$ \\
\hline Irregularly & 36.1 & $(-)$ & 27.5 & $(-)$ & 31.8 & $(-)$ \\
\hline N.R & 1.6 & $(-)$ & 1.3 & $(-)$ & 1.4 & $(-)$ \\
\hline \multicolumn{7}{|l|}{ Sending channel (\%) } \\
\hline Money transfer services & 66.8 & $(-)$ & 83.0 & $(-)$ & 74.9 & $(-)$ \\
\hline Bank & 1.3 & $(-)$ & 3.1 & $(-)$ & 2.2 & $(-)$ \\
\hline Post office & 6.3 & $(-)$ & 4.2 & $(-)$ & 5.3 & $(-)$ \\
\hline Hand-to-hand & 9.2 & $(-)$ & 2.4 & $(-)$ & 5.8 & $(-)$ \\
\hline Fax/telephone/shopkeeper & 14.0 & $(-)$ & 0.3 & $(-)$ & 7.1 & $(-)$ \\
\hline Other & 0.3 & $(-)$ & 0.8 & $(-)$ & 0.5 & $(-)$ \\
\hline N.R & 2.1 & $(-)$ & 6.3 & $(-)$ & 4.2 & $(-)$ \\
\hline Observations $^{(b)}$ & \multicolumn{2}{|c|}{379} & \multicolumn{2}{|c|}{382} & \multicolumn{2}{|c|}{761} \\
\hline
\end{tabular}

Source: MIDDAS Survey, 2009

Remitted amounts are computed on the subsample of migrants with non-zero transfers

(a) One observation per migrant

(b) One observation per recipient in the origin household 
Table 5: Source of financial and non-financial support received by migrants

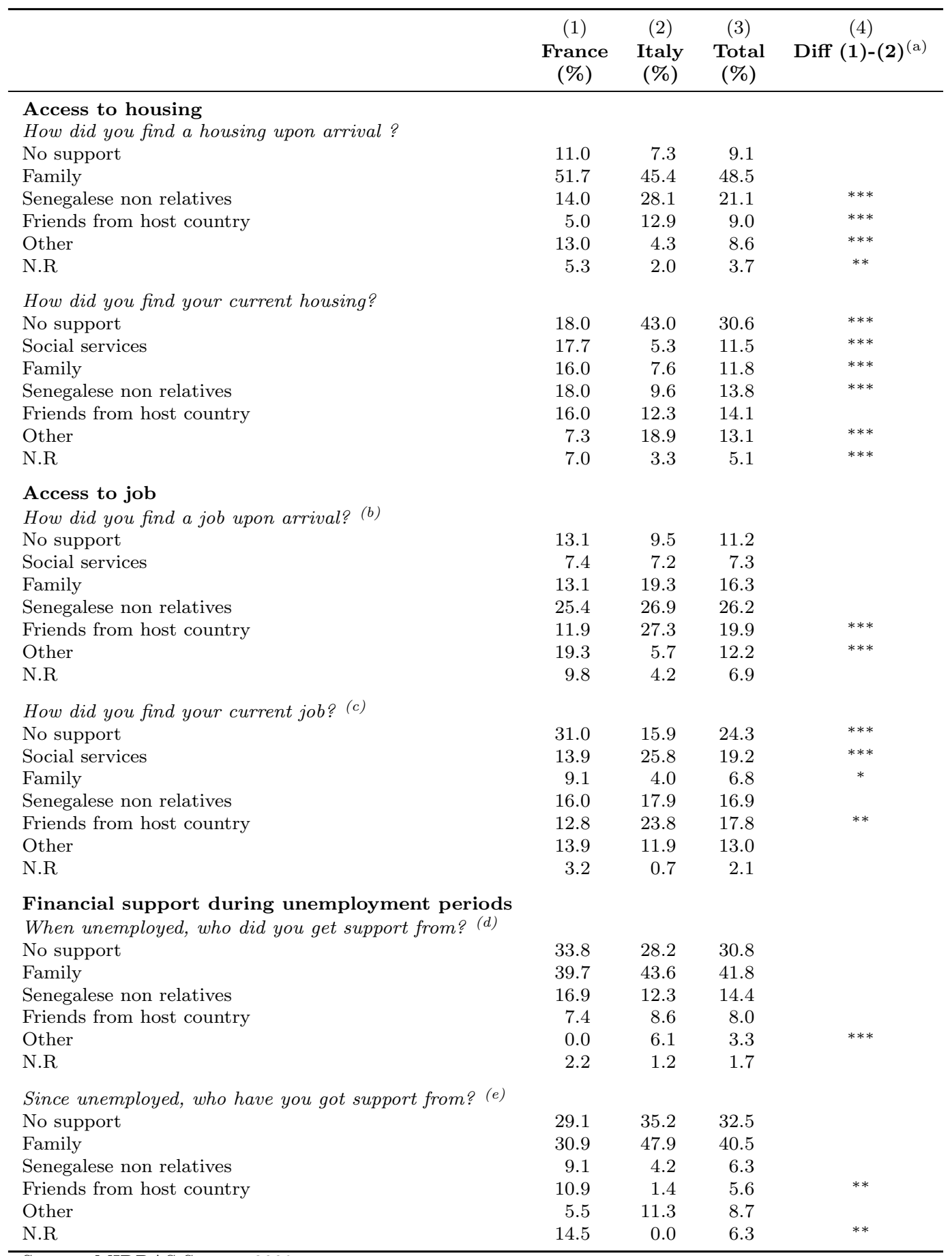

Source: MIDDAS Survey, 2009

(a) Test for equality of the two columns: $* * *$ indicates $1 \%$ significance level, ${ }^{*} 5 \%$ significance level and $* 10 \%$ significance level

(b) Among those who ever worked since arrival

(c) Among those regularly employed

(d) Among those currently employed, with past unemployment spells

(e) Among those currently unemployed 
Table 6: Likelihood of regular remittances - LPM and Probit

\begin{tabular}{|c|c|c|c|c|c|c|}
\hline \multirow{2}{*}{$\begin{array}{l}\text { Dependant variable: Probability to } \\
\text { remit monthly cash in Senegal }\end{array}$} & \multicolumn{2}{|c|}{ Pooled } & \multicolumn{2}{|c|}{ France } & \multicolumn{2}{|c|}{ Italy } \\
\hline & $\begin{array}{l}\mathrm{LPM} \\
(1)\end{array}$ & $\begin{array}{l}\text { Probit } \\
(2)\end{array}$ & $\begin{array}{c}\text { LPM } \\
(3)\end{array}$ & $\begin{array}{c}\text { Probit } \\
(4)\end{array}$ & $\begin{array}{c}\mathrm{LPM} \\
(5)\end{array}$ & $\begin{array}{l}\text { Probit } \\
(6)\end{array}$ \\
\hline \multicolumn{7}{|l|}{ Network valuation $\left(\theta_{i}\right)$} \\
\hline Insecure job or unemployed (d) & $\begin{array}{c}-0.092^{* *} \\
(0.046)\end{array}$ & $\begin{array}{c}-0.104^{* *} \\
(0.052)\end{array}$ & $\begin{array}{c}0.004 \\
(0.070)\end{array}$ & $\begin{array}{l}0.016 \\
(0.086)\end{array}$ & $\begin{array}{c}-0.158^{* *} \\
(0.066)\end{array}$ & $\begin{array}{c}-0.191^{* * *} \\
(0.074)\end{array}$ \\
\hline \multicolumn{7}{|l|}{ Network services $\left(b_{i}\right)$} \\
\hline Senegalese network help (d) & $\begin{array}{l}0.016 \\
(0.047)\end{array}$ & $\begin{array}{l}0.020 \\
(0.054)\end{array}$ & $\begin{array}{c}0.004 \\
(0.071)\end{array}$ & $\begin{array}{c}0.018 \\
(0.088)\end{array}$ & $\begin{array}{c}0.055 \\
(0.064)\end{array}$ & $\begin{array}{c}0.078 \\
(0.076)\end{array}$ \\
\hline Family network help (d) & $\begin{array}{c}0.049 \\
(0.049)\end{array}$ & $\begin{array}{c}0.060 \\
(0.059)\end{array}$ & $\begin{array}{l}-0.007 \\
(0.073)\end{array}$ & $\begin{array}{l}-0.026 \\
(0.090)\end{array}$ & $\begin{array}{c}0.054 \\
(0.073)\end{array}$ & $\begin{array}{c}0.054 \\
(0.087)\end{array}$ \\
\hline Member of Senegalese association (d) & $\begin{array}{c}0.030 \\
(0.049)\end{array}$ & $\begin{array}{c}0.027 \\
(0.058)\end{array}$ & $\begin{array}{l}-0.065 \\
(0.080)\end{array}$ & $\begin{array}{l}-0.108 \\
(0.107)\end{array}$ & $\begin{array}{c}0.050 \\
(0.063)\end{array}$ & $\begin{array}{c}0.050 \\
(0.075)\end{array}$ \\
\hline \multicolumn{7}{|l|}{ Network control $\left(\alpha_{i}\right)$} \\
\hline Size of social network & $\begin{array}{l}-0.022 \\
(0.014)\end{array}$ & $\begin{array}{c}-0.026^{*} \\
(0.015)\end{array}$ & $\begin{array}{l}-0.009 \\
(0.018)\end{array}$ & $\begin{array}{l}-0.017 \\
(0.021)\end{array}$ & $\begin{array}{l}-0.037 \\
(0.026)\end{array}$ & $\begin{array}{l}-0.043 \\
(0.028)\end{array}$ \\
\hline Older Senegalese in social network (d) & $\begin{array}{l}-0.018 \\
(0.078)\end{array}$ & $\begin{array}{l}-0.028 \\
(0.089)\end{array}$ & $\begin{array}{l}-0.056 \\
(0.094)\end{array}$ & $\begin{array}{l}-0.082 \\
(0.121)\end{array}$ & $\begin{array}{l}-0.005 \\
(0.126)\end{array}$ & $\begin{array}{l}-0.028 \\
(0.140)\end{array}$ \\
\hline Senegalese only network (d) & $\begin{array}{c}0.030 \\
(0.053)\end{array}$ & $\begin{array}{c}0.037 \\
(0.060)\end{array}$ & $\begin{array}{c}0.061 \\
(0.079)\end{array}$ & $\begin{array}{c}0.072 \\
(0.093)\end{array}$ & $\begin{array}{c}0.087 \\
(0.072)\end{array}$ & $\begin{array}{c}0.114 \\
(0.085)\end{array}$ \\
\hline Kin in social network (d) & $\begin{array}{c}0.037 \\
(0.051)\end{array}$ & $\begin{array}{c}0.049 \\
(0.059)\end{array}$ & $\begin{array}{c}0.086 \\
(0.071)\end{array}$ & $\begin{array}{c}0.126 \\
(0.086)\end{array}$ & $\begin{array}{l}-0.019 \\
(0.075)\end{array}$ & $\begin{array}{l}-0.022 \\
(0.086)\end{array}$ \\
\hline Network strength index & $\begin{array}{c}0.002 \\
(0.009) \\
\end{array}$ & $\begin{array}{c}0.003 \\
(0.011) \\
\end{array}$ & $\begin{array}{l}-0.017 \\
(0.015) \\
\end{array}$ & $\begin{array}{l}-0.019 \\
(0.018)\end{array}$ & $\begin{array}{c}0.008 \\
(0.012) \\
\end{array}$ & $\begin{array}{c}0.007 \\
(0.014) \\
\end{array}$ \\
\hline
\end{tabular}


Table 6 (continued)

\begin{tabular}{|c|c|c|c|c|c|c|}
\hline \multicolumn{7}{|l|}{ Migrant characteristics } \\
\hline Male (d) & $\begin{array}{c}0.077 \\
(0.056)\end{array}$ & $\begin{array}{c}0.088 \\
(0.064)\end{array}$ & $\begin{array}{c}0.082 \\
(0.077)\end{array}$ & $\begin{array}{c}0.107 \\
(0.096)\end{array}$ & $\begin{array}{c}0.085 \\
(0.087)\end{array}$ & $\begin{array}{c}0.100 \\
(0.098)\end{array}$ \\
\hline Age & $\begin{array}{c}0.051^{* * *} \\
(0.017)\end{array}$ & $\begin{array}{c}0.060^{* * *} \\
(0.019)\end{array}$ & $\begin{array}{c}0.043^{* *} \\
(0.021)\end{array}$ & $\begin{array}{c}0.070^{* * *} \\
(0.027)\end{array}$ & $\begin{array}{c}0.059^{* *} \\
(0.028)\end{array}$ & $\begin{array}{c}0.066^{* *} \\
(0.031)\end{array}$ \\
\hline Age squared $(/ 100)$ & $\begin{array}{c}-0.061^{* * *} \\
(0.022)\end{array}$ & $\begin{array}{c}-0.073^{* * *} \\
(0.025)\end{array}$ & $\begin{array}{c}-0.044^{*} \\
(0.026)\end{array}$ & $\begin{array}{c}-0.074^{* *} \\
(0.033)\end{array}$ & $\begin{array}{c}-0.081^{* *} \\
(0.038)\end{array}$ & $\begin{array}{c}-0.092^{* *} \\
(0.041)\end{array}$ \\
\hline No/elementary schooling (d) & $\begin{array}{c}0.077 \\
(0.055)\end{array}$ & $\begin{array}{c}0.089 \\
(0.062)\end{array}$ & $\begin{array}{c}0.105 \\
(0.079)\end{array}$ & $\begin{array}{c}0.133 \\
(0.095)\end{array}$ & $\begin{array}{l}-0.002 \\
(0.081)\end{array}$ & $\begin{array}{l}-0.009 \\
(0.091)\end{array}$ \\
\hline Attended university (d) & $\begin{array}{c}0.030 \\
(0.053)\end{array}$ & $\begin{array}{c}0.034 \\
(0.061)\end{array}$ & $\begin{array}{l}-0.014 \\
(0.094)\end{array}$ & $\begin{array}{l}-0.029 \\
(0.109)\end{array}$ & $\begin{array}{c}0.083 \\
(0.068)\end{array}$ & $\begin{array}{c}0.112 \\
(0.079)\end{array}$ \\
\hline Total monthly income & $\begin{array}{c}0.043^{* * *} \\
(0.008)\end{array}$ & $\begin{array}{c}0.048^{* * *} \\
(0.009)\end{array}$ & $\begin{array}{c}0.049^{* * *} \\
(0.012)\end{array}$ & $\begin{array}{c}0.066^{* * *} \\
(0.016)\end{array}$ & $\begin{array}{c}0.041^{* * *} \\
(0.012)\end{array}$ & $\begin{array}{c}0.046^{* * *} \\
(0.014)\end{array}$ \\
\hline Total monthly income squared $(/ 100)$ & $\begin{array}{c}-0.109 * * * \\
(0.032)\end{array}$ & $\begin{array}{c}-0.122^{* * *} \\
(0.034)\end{array}$ & $\begin{array}{c}-0.098^{* * *} \\
(0.038)\end{array}$ & $\begin{array}{c}-0.136^{* * *} \\
(0.048)\end{array}$ & $\begin{array}{c}-0.131^{* *} \\
(0.051)\end{array}$ & $\begin{array}{c}-0.150^{* * *} \\
(0.056)\end{array}$ \\
\hline Time since arrival & $\begin{array}{c}0.001 \\
(0.004)\end{array}$ & $\begin{array}{c}0.002 \\
(0.005)\end{array}$ & $\begin{array}{l}-0.004 \\
(0.005)\end{array}$ & $\begin{array}{l}-0.005 \\
(0.006)\end{array}$ & $\begin{array}{c}0.008 \\
(0.007)\end{array}$ & $\begin{array}{c}0.010 \\
(0.008)\end{array}$ \\
\hline Koranic schooling (d) & $\begin{array}{c}0.049 \\
(0.063)\end{array}$ & $\begin{array}{c}0.052 \\
(0.069)\end{array}$ & $\begin{array}{c}0.192^{* *} \\
(0.086)\end{array}$ & $\begin{array}{c}0.218^{* *} \\
(0.100)\end{array}$ & $\begin{array}{l}-0.134 \\
(0.085)\end{array}$ & $\begin{array}{l}-0.151 \\
(0.112)\end{array}$ \\
\hline Intention to return $(\mathrm{d})$ & $\begin{array}{c}0.030 \\
(0.044)\end{array}$ & $\begin{array}{c}0.040 \\
(0.051)\end{array}$ & $\begin{array}{c}0.077 \\
(0.064)\end{array}$ & $\begin{array}{c}0.111 \\
(0.079)\end{array}$ & $\begin{array}{c}0.009 \\
(0.061)\end{array}$ & $\begin{array}{c}0.017 \\
(0.073)\end{array}$ \\
\hline \multicolumn{7}{|l|}{ Recipient household characteristics } \\
\hline Wealth score & $\begin{array}{c}0.010 \\
(0.007)\end{array}$ & $\begin{array}{c}0.011 \\
(0.008)\end{array}$ & $\begin{array}{c}0.010 \\
(0.011)\end{array}$ & $\begin{array}{c}0.014 \\
(0.015)\end{array}$ & $\begin{array}{l}0.015^{*} \\
(0.009)\end{array}$ & $\begin{array}{l}0.017^{*} \\
(0.010)\end{array}$ \\
\hline Rural area $(d)$ & $\begin{array}{c}0.010 \\
(0.060)\end{array}$ & $\begin{array}{c}0.021 \\
(0.070)\end{array}$ & $\begin{array}{c}0.116 \\
(0.072)\end{array}$ & $\begin{array}{c}0.176^{* *} \\
(0.089)\end{array}$ & $\begin{array}{c}-0.206^{* *} \\
(0.091)\end{array}$ & $\begin{array}{c}-0.263^{* *} \\
(0.118)\end{array}$ \\
\hline Resident Spouse/child (d) & $\begin{array}{c}0.117^{* *} \\
(0.051)\end{array}$ & $\begin{array}{c}0.137^{* *} \\
(0.057)\end{array}$ & $\begin{array}{c}0.172^{* *} \\
(0.082)\end{array}$ & $\begin{array}{c}0.222^{* *} \\
(0.093)\end{array}$ & $\begin{array}{c}0.086 \\
(0.068)\end{array}$ & $\begin{array}{c}0.107 \\
(0.078)\end{array}$ \\
\hline Number of other migrants & $\begin{array}{l}-0.005 \\
(0.013)\end{array}$ & $\begin{array}{l}-0.007 \\
(0.014)\end{array}$ & $\begin{array}{l}-0.007 \\
(0.018)\end{array}$ & $\begin{array}{l}-0.014 \\
(0.022)\end{array}$ & $\begin{array}{l}-0.019 \\
(0.017)\end{array}$ & $\begin{array}{l}-0.022 \\
(0.020)\end{array}$ \\
\hline Resident in Italy (d) & $\begin{array}{c}0.068 \\
(0.050)\end{array}$ & $\begin{array}{c}0.085 \\
(0.058)\end{array}$ & & & & \\
\hline Constant & $\begin{array}{c}-0.946^{* * *} \\
(0.326)\end{array}$ & & $\begin{array}{c}-1.048^{* *} \\
(0.402)\end{array}$ & & $\begin{array}{l}-0.680 \\
(0.545)\end{array}$ & \\
\hline Observations & 458 & 458 & 212 & 212 & 246 & 246 \\
\hline
\end{tabular}

Source: MIDDAS Survey, 2009

Note: Coefficient for LPM and marginal effects for Probit; robust standard errors in parentheses

${ }^{*} p<0.10,{ }^{* *} p<0.05,{ }^{* * *} p<0.01$

(d) stands for dummy variables 


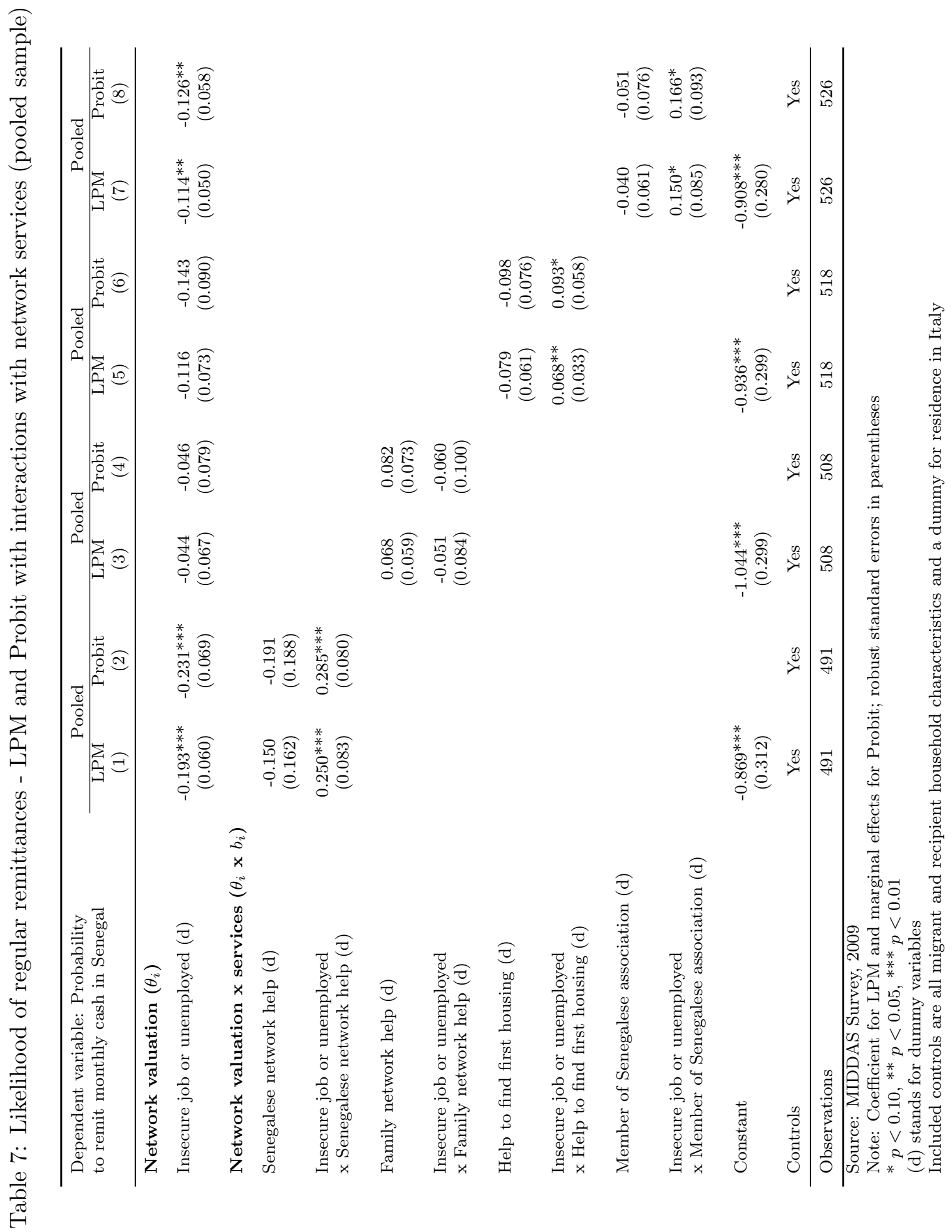




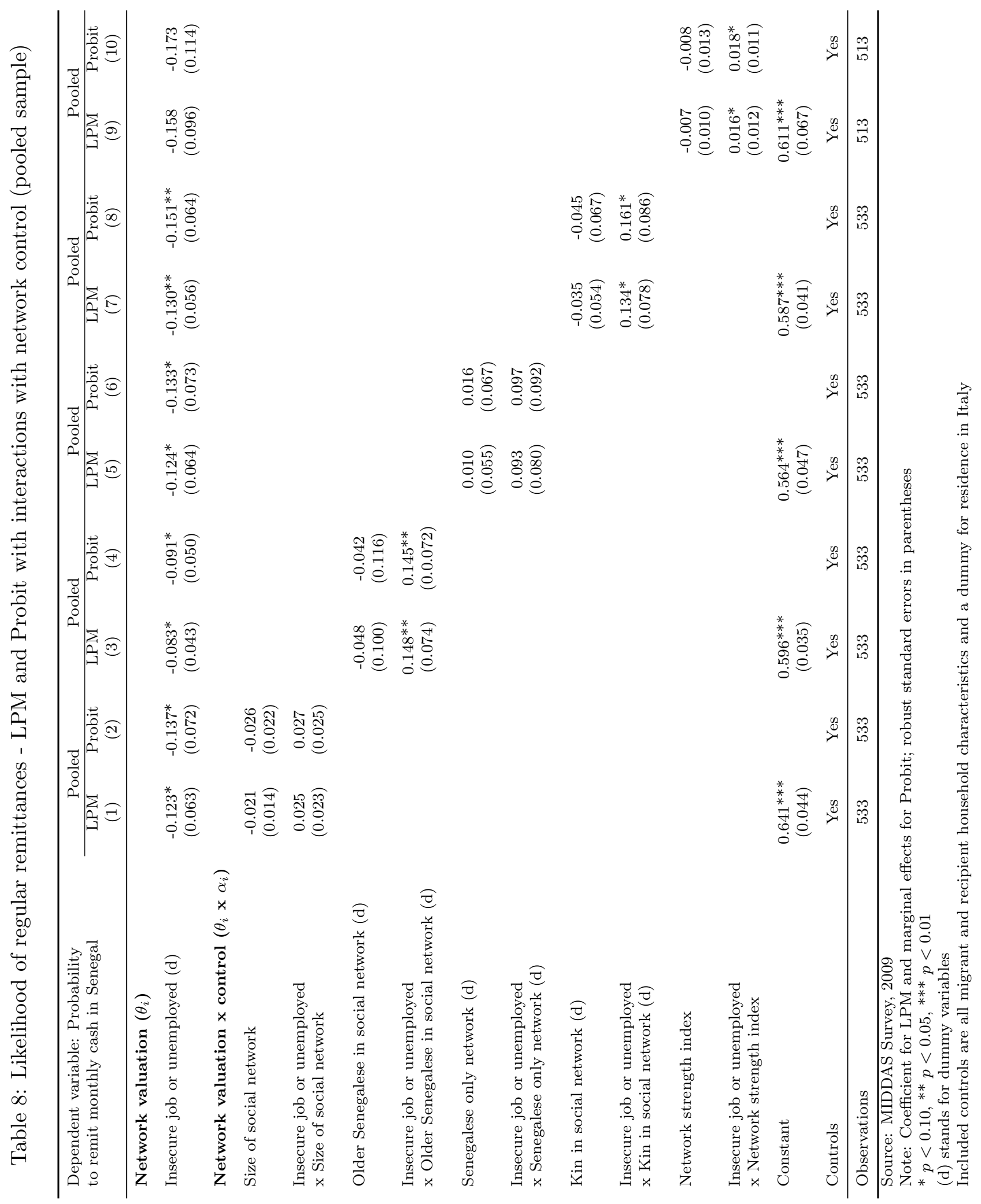


Table 9: Remittance amounts - OLS and Tobit

\begin{tabular}{|c|c|c|c|c|c|c|}
\hline \multirow{2}{*}{$\begin{array}{l}\text { Dependant variable: Total amount } \\
\text { remitted in cash/kind in Senegal }\end{array}$} & \multicolumn{2}{|c|}{ Pooled } & \multicolumn{2}{|c|}{ France } & \multicolumn{2}{|c|}{ Italy } \\
\hline & $\begin{array}{l}\text { OLS } \\
(1)\end{array}$ & $\begin{array}{l}\text { Tobit } \\
(2)\end{array}$ & $\begin{array}{l}\text { OLS } \\
(3)\end{array}$ & $\begin{array}{c}\text { Tobit } \\
(4)\end{array}$ & $\begin{array}{l}\text { OLS } \\
(5)\end{array}$ & $\begin{array}{c}\text { Tobit } \\
(6)\end{array}$ \\
\hline \multicolumn{7}{|l|}{ Network valuation $\left(\theta_{i}\right)$} \\
\hline Insecure job or unemployed (d) & $\begin{array}{l}-240.9 \\
(199.6)\end{array}$ & $\begin{array}{l}-189.8 \\
(136.3)\end{array}$ & $\begin{array}{l}-188.3 \\
(240.8)\end{array}$ & $\begin{array}{l}-141.3 \\
(170.5)\end{array}$ & $\begin{array}{c}22.4 \\
(329.5)\end{array}$ & $\begin{array}{c}-37.9 \\
(215.5)\end{array}$ \\
\hline \multicolumn{7}{|l|}{ Network services $\left(b_{i}\right)$} \\
\hline Family network help (d) & $\begin{array}{l}198.5 \\
(227.8)\end{array}$ & $\begin{array}{c}136.9 \\
(153.3)\end{array}$ & $\begin{array}{l}167.8 \\
(304.6)\end{array}$ & $\begin{array}{l}110.7 \\
(210.9)\end{array}$ & $\begin{array}{c}282.6 \\
(362.7)\end{array}$ & $\begin{array}{c}198.0 \\
(231.4)\end{array}$ \\
\hline Senegalese network help (d) & $\begin{array}{c}12.8 \\
(192.2)\end{array}$ & $\begin{array}{c}44.9 \\
(132.7)\end{array}$ & $\begin{array}{c}251.7 \\
(288.1)\end{array}$ & $\begin{array}{c}302.1 \\
(197.7)\end{array}$ & $\begin{array}{l}-156.2 \\
(278.0)\end{array}$ & $\begin{array}{l}-135.2 \\
(188.3)\end{array}$ \\
\hline Member of Senegalese association (d) & $\begin{array}{c}143.3 \\
(208.4)\end{array}$ & $\begin{array}{c}144.7 \\
(142.9)\end{array}$ & $\begin{array}{l}-169.3 \\
(317.9)\end{array}$ & $\begin{array}{l}-131.6 \\
(200.3)\end{array}$ & $\begin{array}{c}206.8 \\
(280.8)\end{array}$ & $\begin{array}{c}183.9 \\
(190.8)\end{array}$ \\
\hline \multicolumn{7}{|l|}{ Network control $\left(\alpha_{i}\right)$} \\
\hline Size of social network & $\begin{array}{c}-38.1 \\
(53.3)\end{array}$ & $\begin{array}{l}-25.8 \\
(36.0)\end{array}$ & $\begin{array}{l}-27.4 \\
(66.3)\end{array}$ & $\begin{array}{c}-19.6 \\
(44.1)\end{array}$ & $\begin{array}{c}26.4 \\
(91.9)\end{array}$ & $\begin{array}{c}32.6 \\
(64.6)\end{array}$ \\
\hline Older Senegalese in social network (d) & $\begin{array}{c}219.3 \\
(290.2)\end{array}$ & $\begin{array}{c}171.1 \\
(216.4)\end{array}$ & $\begin{array}{c}-14.3 \\
(276.1)\end{array}$ & $\begin{array}{c}31.3 \\
(195.4)\end{array}$ & $\begin{array}{c}263.9 \\
(531.1)\end{array}$ & $\begin{array}{c}170.6 \\
(395.2)\end{array}$ \\
\hline Senegalese only network (d) & $\begin{array}{c}118.4 \\
(196.5)\end{array}$ & $\begin{array}{c}85.2 \\
(137.6)\end{array}$ & $\begin{array}{l}482.1^{*} \\
(262.8)\end{array}$ & $\begin{array}{l}347.8^{*} \\
(189.0)\end{array}$ & $\begin{array}{c}-47.4 \\
(290.7)\end{array}$ & $\begin{array}{c}-9.6 \\
(198.2)\end{array}$ \\
\hline Kin in social network (d) & $\begin{array}{c}102.2 \\
(198.7)\end{array}$ & $\begin{array}{c}75.9 \\
(140.4)\end{array}$ & $\begin{array}{c}8.8 \\
(266.1)\end{array}$ & $\begin{array}{c}0.4 \\
(189.8)\end{array}$ & $\begin{array}{c}59.0 \\
(309.4)\end{array}$ & $\begin{array}{c}42.3 \\
(214.7)\end{array}$ \\
\hline Network strength index & $\begin{array}{l}-50.2 \\
(41.7) \\
\end{array}$ & $\begin{array}{l}-37.9 \\
(28.5)\end{array}$ & $\begin{array}{r}-141.6 \\
(66.4) \\
\end{array}$ & $\begin{array}{c}-108.6 \\
(83.0)\end{array}$ & $\begin{array}{l}-18.5 \\
(62.1)\end{array}$ & $\begin{array}{l}-23.8 \\
(35.5) \\
\end{array}$ \\
\hline
\end{tabular}


Table 9 (continued)

\begin{tabular}{|c|c|c|c|c|c|c|}
\hline \multicolumn{7}{|l|}{ Migrant characteristics } \\
\hline Male (d) & $\begin{array}{l}452.9^{*} \\
(235.0)\end{array}$ & $\begin{array}{l}293.8^{*} \\
(159.7)\end{array}$ & $\begin{array}{c}337.1 \\
(307.8)\end{array}$ & $\begin{array}{c}303.5 \\
(210.8)\end{array}$ & $\begin{array}{c}585.8 \\
(365.9)\end{array}$ & $\begin{array}{c}320.1 \\
(241.2)\end{array}$ \\
\hline Age & $\begin{array}{c}24.2 \\
(77.7)\end{array}$ & $\begin{array}{c}37.9 \\
(54.1)\end{array}$ & $\begin{array}{c}-38.8 \\
(107.0)\end{array}$ & $\begin{array}{c}7.5 \\
(75.6)\end{array}$ & $\begin{array}{c}73.4 \\
(124.9)\end{array}$ & $\begin{array}{c}34.9 \\
(86.1)\end{array}$ \\
\hline Age squared $(/ 100)$ & $\begin{array}{c}-3.6 \\
(102.0)\end{array}$ & $\begin{array}{l}-25.1 \\
(69.6)\end{array}$ & $\begin{array}{c}95.8 \\
(132.6)\end{array}$ & $\begin{array}{c}34.9 \\
(93.7)\end{array}$ & $\begin{array}{c}-97.4 \\
(172.7)\end{array}$ & $\begin{array}{c}-47.1 \\
(115.7)\end{array}$ \\
\hline No/elementary schooling (d) & $\begin{array}{c}258.9 \\
(215.5)\end{array}$ & $\begin{array}{c}161.3 \\
(159.8)\end{array}$ & $\begin{array}{l}590.4^{*} \\
(349.0)\end{array}$ & $\begin{array}{c}385.1 \\
(257.8)\end{array}$ & $\begin{array}{l}-113.6 \\
(315.4)\end{array}$ & $\begin{array}{c}-61.5 \\
(226.3)\end{array}$ \\
\hline Attended university (d) & $\begin{array}{c}126.9 \\
(241.2)\end{array}$ & $\begin{array}{c}73.6 \\
(168.3)\end{array}$ & $\begin{array}{c}137.2 \\
(305.4)\end{array}$ & $\begin{array}{c}17.1 \\
(220.0)\end{array}$ & $\begin{array}{c}175.3 \\
(355.8)\end{array}$ & $\begin{array}{c}195.3 \\
(239.5)\end{array}$ \\
\hline Total monthly income & $\begin{array}{c}98.7^{* *} \\
(43.2)\end{array}$ & $\begin{array}{c}89.0^{* * * *} \\
(30.6)\end{array}$ & $\begin{array}{c}88.9 \\
(61.7)\end{array}$ & $\begin{array}{c}90.4^{* *} \\
(45.2)\end{array}$ & $\begin{array}{c}181.2^{* * *} \\
(48.4)\end{array}$ & $\begin{array}{c}136.0^{* * *} \\
(34.3)\end{array}$ \\
\hline Total monthly income squared $(/ 100)$ & $\begin{array}{c}-24.5 \\
(193.4)\end{array}$ & $\begin{array}{c}-78.5 \\
(129.9)\end{array}$ & $\begin{array}{c}154.9 \\
(228.4)\end{array}$ & $\begin{array}{c}38.8 \\
(157.8)\end{array}$ & $\begin{array}{c}-508.4^{* * *} \\
(194.5)\end{array}$ & $\begin{array}{c}-372.6^{* * *} \\
(131.4)\end{array}$ \\
\hline Time since arrival & $\begin{array}{c}8.7 \\
(18.0)\end{array}$ & $\begin{array}{c}4.0 \\
(12.6)\end{array}$ & $\begin{array}{l}-18.5 \\
(23.9)\end{array}$ & $\begin{array}{l}-19.9 \\
(17.4)\end{array}$ & $\begin{array}{c}52.5 \\
(32.3)\end{array}$ & $\begin{array}{l}44.3^{* *} \\
(20.7)\end{array}$ \\
\hline Koranic schooling (d) & $\begin{array}{c}634.3^{* * *} \\
(206.4)\end{array}$ & $\begin{array}{c}396.9^{* * *} \\
(136.2)\end{array}$ & $\begin{array}{c}836.3^{* * *} \\
(254.3)\end{array}$ & $\begin{array}{c}592.1^{* * *} \\
(160.9)\end{array}$ & $\begin{array}{c}318.3 \\
(308.7)\end{array}$ & $\begin{array}{c}158.2 \\
(216.4)\end{array}$ \\
\hline Intention to return $(\mathrm{d})$ & $\begin{array}{c}223.7 \\
(187.4)\end{array}$ & $\begin{array}{c}145.6 \\
(132.0)\end{array}$ & $\begin{array}{c}348.6 \\
(263.0)\end{array}$ & $\begin{array}{c}276.0 \\
(183.9)\end{array}$ & $\begin{array}{c}75.2 \\
(275.5)\end{array}$ & $\begin{array}{c}6.8 \\
(192.3)\end{array}$ \\
\hline \multicolumn{7}{|l|}{ Recipient household characteristics } \\
\hline Wealth score & $\begin{array}{l}72.1^{* *} \\
(32.2)\end{array}$ & $\begin{array}{c}53.5^{* * *} * \\
(20.2)\end{array}$ & $\begin{array}{l}97.9^{*} \\
(58.6)\end{array}$ & $\begin{array}{l}70.3^{*} \\
(37.4)\end{array}$ & $\begin{array}{c}54.4 \\
(40.0)\end{array}$ & $\begin{array}{l}45.0^{*} \\
(25.1)\end{array}$ \\
\hline Rural area $(\mathrm{d})$ & $\begin{array}{c}264.5 \\
(232.6)\end{array}$ & $\begin{array}{c}236.4 \\
(167.9)\end{array}$ & $\begin{array}{c}593.0^{* *} \\
(279.6)\end{array}$ & $\begin{array}{c}514.6^{* *} \\
(205.5)\end{array}$ & $\begin{array}{c}-90.2 \\
(401.9)\end{array}$ & $\begin{array}{l}-121.6 \\
(273.6)\end{array}$ \\
\hline Resident Spouse/child (d) & $\begin{array}{c}727.0^{* * *} \\
(267.9)\end{array}$ & $\begin{array}{c}529.2^{* * *} \\
(185.0)\end{array}$ & $\begin{array}{c}828.5^{* *} \\
(401.4)\end{array}$ & $\begin{array}{c}574.2^{* *} \\
(289.0)\end{array}$ & $\begin{array}{l}690.3^{*} \\
(350.3)\end{array}$ & $\begin{array}{c}540.8^{* *} \\
(231.5)\end{array}$ \\
\hline Number of other migrants & $\begin{array}{c}26.3 \\
(46.5)\end{array}$ & $\begin{array}{c}20.9 \\
(32.1)\end{array}$ & $\begin{array}{c}9.0 \\
(60.8)\end{array}$ & $\begin{array}{c}-8.6 \\
(42.3)\end{array}$ & $\begin{array}{c}18.4 \\
(70.9)\end{array}$ & $\begin{array}{c}31.1 \\
(47.5)\end{array}$ \\
\hline Resident in Italy (d) & $\begin{array}{c}109.2 \\
(208.9)\end{array}$ & $\begin{array}{c}35.0 \\
(146.2)\end{array}$ & & & & \\
\hline Constant & $\begin{array}{l}-1305.7 \\
(1410.4)\end{array}$ & $(1609.9)$ & $\begin{array}{c}-418.9 \\
(1846.2)\end{array}$ & $(2003.3)$ & $\begin{array}{l}-1779.7 \\
(2507.5)\end{array}$ & $(2831.1)$ \\
\hline Observations & 417 & 417 & 203 & 203 & 214 & 214 \\
\hline
\end{tabular}




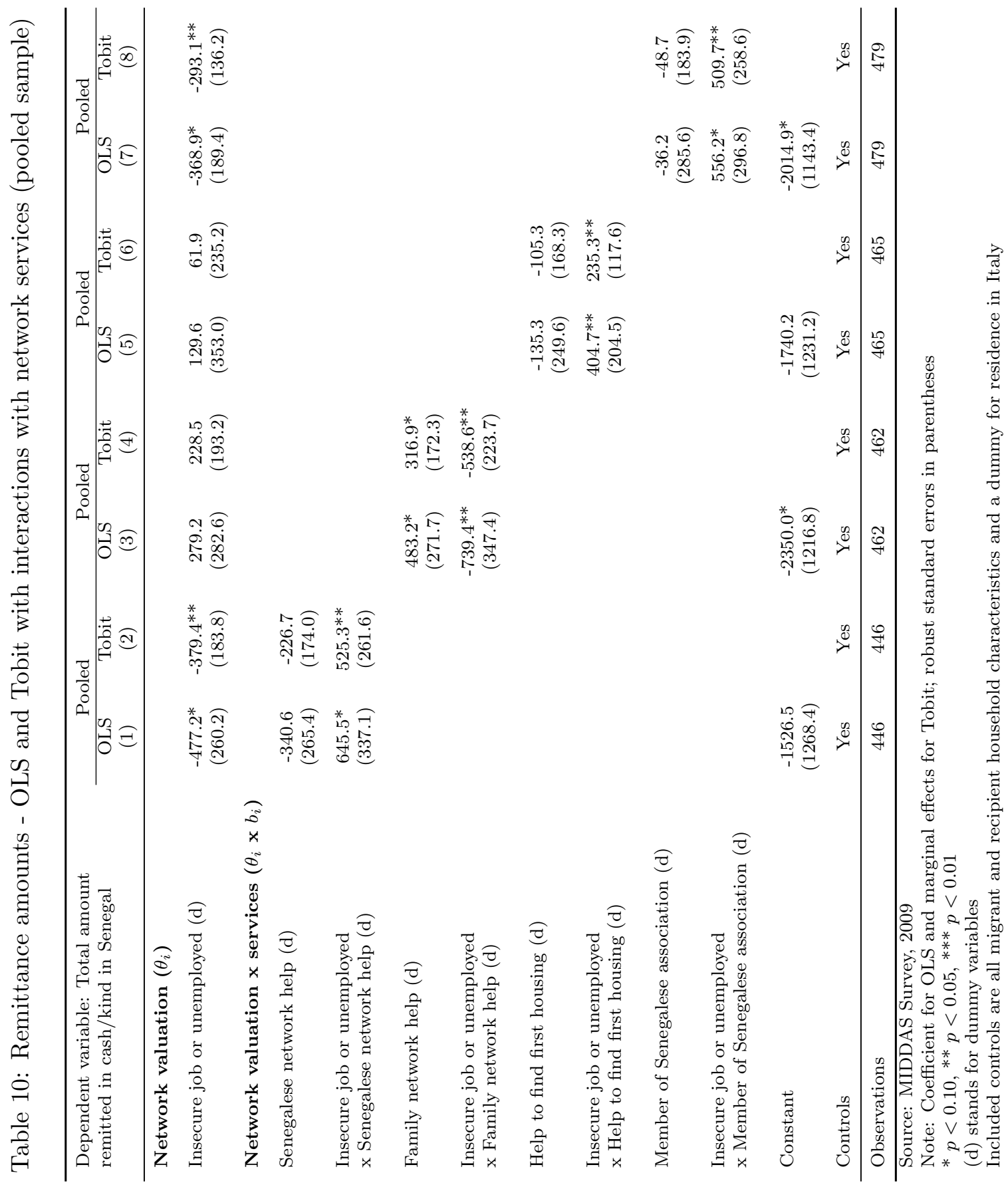




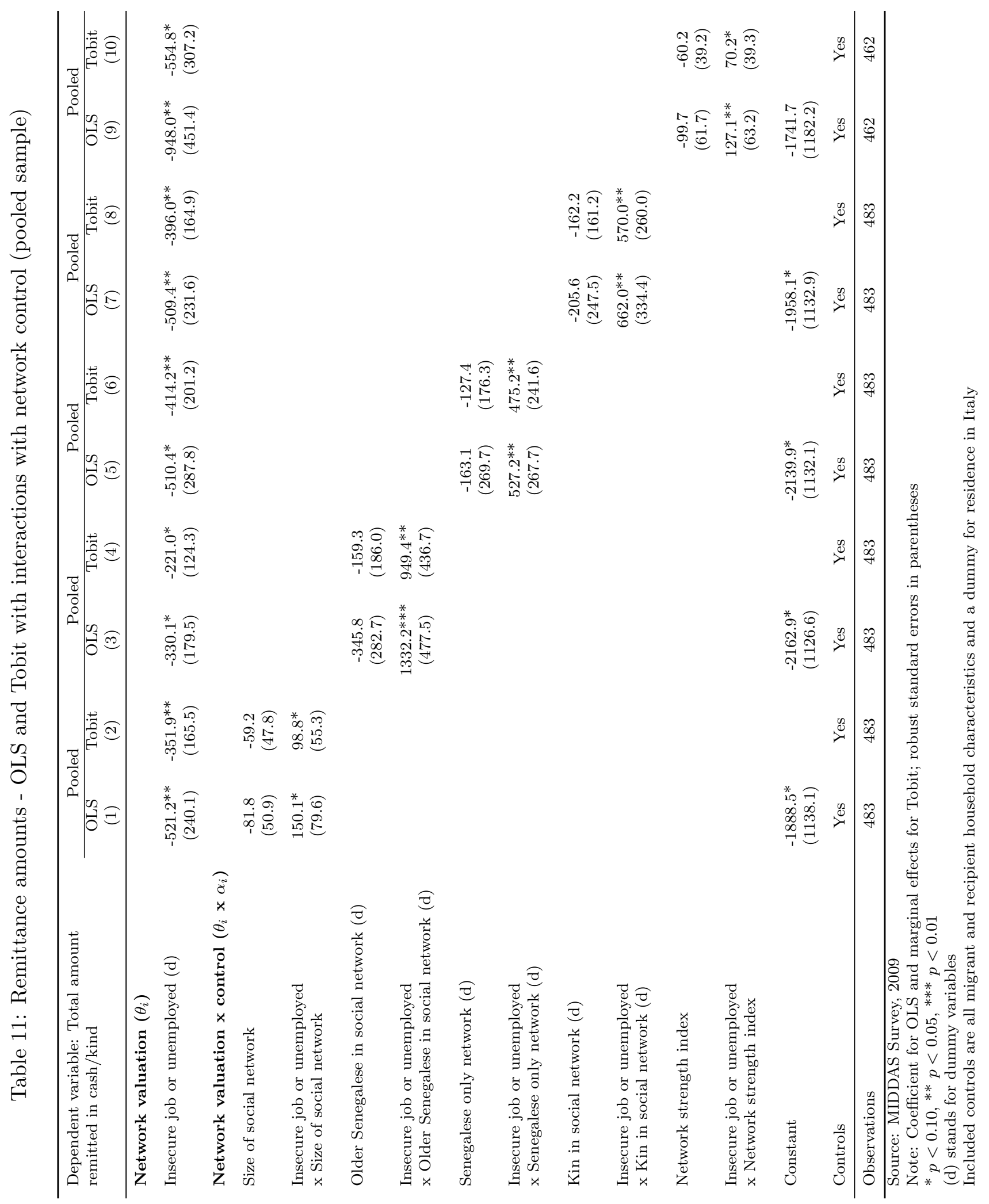




\section{Appendix}

Table 12: List of variables

\begin{tabular}{|c|c|}
\hline Variable & Definition \\
\hline \multicolumn{2}{|l|}{ Migrant characteristics } \\
\hline Male (d) & Equal to one if male \\
\hline Age & Age in years \\
\hline Total monthly income & Total monthly income, including social benefits, in hundred of euros \\
\hline No/elementary schooling (d) & Equal to one if no schooling or attended elementary schooling only \\
\hline Attended university (d) & Equal to one if attended university \\
\hline Koranic schooling $(\mathrm{d})$ & Equal to one if attended Koranic schools \\
\hline Time since arrival & Number of years since arrival in the country of destination (France or Italy) \\
\hline Intention to return $(\mathrm{d})$ & Equal to one if plans to return to Senegal \\
\hline \multicolumn{2}{|l|}{ Recipient household characteristics } \\
\hline Rural area $(d)$ & Equal to one if recipient household is located in rural area \\
\hline Resident spouse/child (d) & Equal to one if migrant's spouses and/or children live in main recipient household \\
\hline Number of other migrants & Number of other migrants originated from the recipient household \\
\hline Wealth index & $\begin{array}{l}\text { First component of a principal component analysis on a set of durable and } \\
\text { equipment goods possessed by the main recipient household: fridges, freezers, } \\
\text { TV, CD, DVD and radio sets, electric fans, bicycles, motorcycles and cars. }\end{array}$ \\
\hline \multicolumn{2}{|l|}{ Network valuation $(\theta)$} \\
\hline Insecure job or unemployed (d) & $\begin{array}{l}\text { Equal to one if unemployed, short-term contract, no contract, seasonal } \\
\text { or undeclared job }\end{array}$ \\
\hline \multicolumn{2}{|l|}{ Network services $(b)$} \\
\hline Member of Senegalese association (d) & Equal to one if member of a Senegalese or Senegal oriented association \\
\hline Family network help (d) & $\begin{array}{l}\text { Equal to one if was helped by family members in the destination country to find } \\
\text { a job, housing or during unemployment periods (currently or upon arrival) }\end{array}$ \\
\hline Senegalese network help (d) & $\begin{array}{l}\text { Equal to one if was helped by non family Senegalese in the destination country } \\
\text { to find a job, housing or during unemployment periods (currently or upon arrival) }\end{array}$ \\
\hline Help to find first housing (d) & $\begin{array}{l}\text { Equal to one if was helped Senegalese in the destination country to find } \\
\text { housing upon arrival }\end{array}$ \\
\hline \multicolumn{2}{|l|}{ Network control $(\alpha)$} \\
\hline Size of social network & Number of listed contacts \\
\hline Older Senegalese in social network (d) & Equal to one if one or more listed contact is at least ten years older \\
\hline Kin in social network $(d)$ & Equal to one if family members or co-villagers among listed contacts \\
\hline Senegalese only network $(d)$ & Equal to one if all listed contacts are Senegalese \\
\hline Network strength index & Inverse of average distance to network members, in travel time \\
\hline
\end{tabular}


Table 13: Likelihood of remittances and access to network services - Bivariate Probit

\begin{tabular}{|c|c|c|c|}
\hline $\begin{array}{l}\text { Dependent variables: } \\
R_{i}=\text { Remit in cash/kind in Senegal } \\
b_{i}=\text { Help by Senegalese or family network }\end{array}$ & $\begin{array}{c}P\left(R_{i}=1\right) \\
(1)\end{array}$ & $\begin{array}{c}P\left(b_{i}=1\right) \\
(2)\end{array}$ & $\begin{array}{c}P\left(R_{i}=1 \& b_{i}=1\right) \\
(3)\end{array}$ \\
\hline \multicolumn{4}{|l|}{ Network valuation $\left(\theta_{i}\right)$} \\
\hline Insecure job or unemployed (d) & $\begin{array}{l}-0.075 \\
(0.049)\end{array}$ & $\begin{array}{c}0.055 \\
(0.042)\end{array}$ & $\begin{array}{l}-0.038 \\
(0.047)\end{array}$ \\
\hline \multicolumn{4}{|l|}{ Migrant characteristics } \\
\hline Male (d) & $\begin{array}{c}0.050 \\
(0.058)\end{array}$ & $\begin{array}{c}-0.095^{* * *} \\
(0.023)\end{array}$ & $\begin{array}{l}-0.006 \\
(0.058)\end{array}$ \\
\hline Age & $\begin{array}{c}0.072^{* * *} \\
(0.018)\end{array}$ & $\begin{array}{c}-0.014 \\
(0.009)\end{array}$ & $\begin{array}{c}0.057^{* * *} \\
(0.017)\end{array}$ \\
\hline Age squared $(/ 100)$ & $\begin{array}{c}-0.085^{* * *} \\
(0.024)\end{array}$ & $\begin{array}{c}0.014 \\
(0.012)\end{array}$ & $\begin{array}{c}-0.069^{* * *} \\
(0.023)\end{array}$ \\
\hline No/elementary schooling (d) & $\begin{array}{l}0.106^{*} \\
(0.059)\end{array}$ & $\begin{array}{l}-0.014 \\
(0.034)\end{array}$ & $\begin{array}{c}0.088 \\
(0.058)\end{array}$ \\
\hline Attended university (d) & $\begin{array}{c}0.019 \\
(0.057)\end{array}$ & $\begin{array}{c}-0.099^{* *} \\
(0.040)\end{array}$ & $\begin{array}{l}-0.040 \\
(0.053)\end{array}$ \\
\hline Total monthly income & $\begin{array}{c}0.053^{* * *} \\
(0.009)\end{array}$ & $\begin{array}{c}0.004 \\
(0.004)\end{array}$ & $\begin{array}{c}0.051^{* * *} \\
(0.008)\end{array}$ \\
\hline Total monthly income squared $(/ 100)$ & $\begin{array}{c}-0.131^{* * *} \\
(0.033)\end{array}$ & $\begin{array}{c}-0.025^{*} \\
(0.014)\end{array}$ & $\begin{array}{c}-0.133^{* * *} \\
(0.030)\end{array}$ \\
\hline Time since arrival & $\begin{array}{l}-0.000 \\
(0.004)\end{array}$ & $\begin{array}{c}0.003 \\
(0.002)\end{array}$ & $\begin{array}{c}0.001 \\
(0.004)\end{array}$ \\
\hline Koranic schooling (d) & $\begin{array}{c}0.064 \\
(0.067)\end{array}$ & $\begin{array}{c}0.044 \\
(0.039)\end{array}$ & $\begin{array}{c}0.081 \\
(0.061)\end{array}$ \\
\hline Intention to return (d) & $\begin{array}{c}0.040 \\
(0.048)\end{array}$ & $\begin{array}{l}-0.012 \\
(0.027)\end{array}$ & $\begin{array}{c}0.029 \\
(0.046)\end{array}$ \\
\hline \multicolumn{4}{|l|}{ Recipient household characteristics } \\
\hline Wealth score & $\begin{array}{l}0.014^{*} \\
(0.009)\end{array}$ & $\begin{array}{c}-0.006 \\
(0.004)\end{array}$ & $\begin{array}{c}0.009 \\
(0.008)\end{array}$ \\
\hline Rural area (d) & $\begin{array}{c}0.001 \\
(0.065)\end{array}$ & $\begin{array}{l}-0.013 \\
(0.034)\end{array}$ & $\begin{array}{l}-0.006 \\
(0.059)\end{array}$ \\
\hline Resident Spouse/child (d) & $\begin{array}{c}0.146^{* * *} \\
(0.053)\end{array}$ & $\begin{array}{c}0.042 \\
(0.026)\end{array}$ & $\begin{array}{c}0.158^{* * *} \\
(0.052)\end{array}$ \\
\hline Number of other migrants & $\begin{array}{l}-0.008 \\
(0.013)\end{array}$ & $\begin{array}{c}0.021^{* *} \\
(0.009)\end{array}$ & $\begin{array}{c}0.005 \\
(0.013)\end{array}$ \\
\hline Resident in Italy (d) & $\begin{array}{c}0.050 \\
(0.053)\end{array}$ & $\begin{array}{c}0.004 \\
(0.026)\end{array}$ & $\begin{array}{l}0.048 \\
(0.050)\end{array}$ \\
\hline Estimated probability & 0.571 & 0.910 & 0.522 \\
\hline Likelihood-ratio test of $\rho=0$ : & .049 & $b>\operatorname{chi} 2=0.825$ & \\
\hline Observations & 523 & 523 & 523 \\
\hline
\end{tabular}

Source: MIDDAS Survey, 2009

Note: Marginal effects; robust standard errors in parentheses

(d) stands for dummy variables

${ }^{*} p<0.10,{ }^{* *} p<0.05,{ }^{* * *} p<0.01$ 


\section{References}

Aguilera, M.B. 2002. "The Impact of Social Capital on Labor Force Participation: Evidence from the 2000 Social Capital Benchmark Survey." Social Science Quarterly 83 (3):853-874.

- 2005. "The impact of social capital on the earnings of Puerto Rican migrants." Sociological Quarterly 46 (4):569-592.

Ai, C. and E.C. Norton. 2003. "Interaction terms in logit and probit models." Economics Letters 80 (1):123-129.

Bertrand, M., E.F.P. Luttmer, and S. Mullainathan. 2000. "tNetwork Effects and Network Cultures." uQuarterly Journal of Economics 115:1019-1055.

Chort, I. 2011. Three essays on migration. Ph.D. thesis, Paris School of Economics - EHESS.

Dia, H. 2007. "Le portable dans la vallée du fleuve Sénégal." Agora 46:70-80.

. 2009. Espaces domestiques, espaces villageois, espaces urbains multi-situés. Cinquante années de migrations à partir de la moyenne vallée du fleuve Sénégal (1960-2010). Ph.D. thesis, Université de Paris 5 Descartes.

Drever, A.I. and O. Hoffmeister. 2008. "Immigrants and Social Networks in a Job-Scarce Environment: The Case of Germany." International Migration Review 42 (2):425-448.

Edin, P.A., P. Fredriksson, and O. Åslund. 2003. "Ethnic enclaves and the economic success of immigrants: Evidence from a natural experiment." The Quarterly Journal of Economics $118(1): 329$

Elia, A. 2006. Les Foulbé de la vallée du Sénégal en Italie. Paris: L’Harmattan.

Gagnepain, P., M. Ivaldi, and D. Martimort. 2009. "Renégociation de contrats dans l'industrie du transport urbain." Revue Économique 60 (4).

Granovetter, M.S. 1995. Getting a job: a study of contacts and careers. University of Chicago Press.

Greif, A. 1989. "Reputation and Coalitions in Medieval Trade: Evidence on the Maghribi Traders." The Journal of Economic History 49 (4):pp. 857-882.

Kankonde, PB. 2010. "Transnational family ties, remittance motives, and social death among Congolese migrants: a socio-anthropological analysis." Journal of Comparative Family Studies 41:225-244.

Lin, N. 1999. "Social networks and status attainment." Annual review of sociology :467-487.

Lydié, N., P. Guilbert, and G. Sliman. 2007. "Exemple de méthodologie pour une enquête auprès des populations d'Afrique subsaharienne." Colloque francophone sur les sondages.

Mazzucato, V. 2009. "Informal Insurance Arrangements in Ghanaian Migrants' Transnational Networks: The Role of Reverse Remittances and Geographic Proximity." World Development 37 (6):1105 - 1115.

Mboup, M. 2001. Les Sénégalais d'Italie. Paris: L'Harmattan. 
McKenzie, D. and H. Rapoport. 2010. "Self-selection patterns in Mexico-US migration: the role of migration networks." The Review of Economics and Statistics 92 (4):811-821.

McKenzie, D.J. and J. Mistiaen. 2009. "Surveying migrant households: a comparison of census-based, snowball and intercept point surveys." Journal of the Royal Statistical Society $172(2): 339-360$.

Menjívar, C. 2002. "The Ties that Heal: Guatemalan Immigrant Women's Networks and Medical Treatment." International Migration Review 36 (2):437-466.

Montgomery, J.D. 1991. "Social networks and labor-market outcomes: Toward an economic analysis." The American economic review 81 (5):1408-1418.

Mouw, T. 2002. "Racial differences in the effects of job contacts: Conflicting evidence from cross-sectional and longitudinal data." Social Science Research 31 (4):511 - 538.

Munshi, K. 2003. "Networks in the Modern Economy: Mexican Migrants in the U. S. Labor Market." The Quarterly Journal of Economics 118 (2):549-599.

Patel, K. and F. Vella. 2007. "Immigrant networks and their implications for occupational choice and wages." IZA Working Paper No. 3217.

Philpott, S.B. 1968. "Remittance Obligations, Social Networks and Choice Among Montserratian Migrants in Britain." Man 3 (3):pp. 465-476.

Rapoport, H. and F. Docquier. 2006. The Economics of Migrants' Remittances, Handbook on the Economics of Giving, Reciprocity and Altruism, vol. 1, chap. 17. Elsevier, 1135-1198.

Roberts, K.D. and M.D.S. Morris. 2003. "Fortune, Risk, and Remittances: An Application of Option Theory to Participation in Village-Based Migration Networks." International Migration Review 37 (4):pp. 1252-1281.

Sana, M. 2005. "Buying membership in the transnational community: migrant remittances, social status, and assimilation." Population research and policy review 24:231-261.

Topa, G. 2001. "Social interactions, local spillovers and unemployment." The Review of Economic Studies 68 (2):261. 